\title{
Autotrophic and heterotrophic activity in Arctic first-year sea ice: seasonal study from Malene Bight, SW Greenland
}

\author{
Dorte Haubjerg Søgaard ${ }^{1,2, *}$, Morten Kristensen ${ }^{1,2}$, Søren Rysgaard ${ }^{1}$, \\ Ronnie Nøhr Glud ${ }^{14}$, Per Juel Hansen ${ }^{2}$, Karen Marie Hilligsøe ${ }^{3}$ \\ ${ }^{1}$ Greenland Climate Research Centre (c/o Greenland Institute of Natural Resources), Kivioq 2, Box 570, 3900 Nuuk, Greenland \\ ${ }^{2}$ University of Copenhagen, Marine Biological Laboratory, Strandpromenaden 5, 3000 Helsingør, Denmark \\ ${ }^{3}$ Aarhus University, Department of Biological Sciences, Ny Munkegade 114-116, 8000 Århus C, Denmark \\ ${ }^{4}$ Present address: The Scottish Association for Marine Science, Oban, Argyll PA37 1QA, Scotland, UK
}

\begin{abstract}
We present a study of autotrophic and heterotrophic activities of Arctic sea ice (Malene Bight, SW Greenland) as measured by 2 different approaches: (1) standard incubation techniques $\left(\mathrm{H}^{14} \mathrm{CO}_{3}{ }^{-}\right.$and $\left[{ }^{3} \mathrm{H}\right]$ thymidine incubation) on sea ice cores brought to the laboratory and (2) cores incubated in situ in plastic bags with subsequent melting and measurements of changes in total $\mathrm{O}_{2}$ concentrations. The standard incubations showed that the annual succession followed a distinctive pattern, with a low, almost balancing heterotrophic and autotrophic activity during February and March. This period was followed by an algal bloom in late March and April, leading to a net autotrophic community. During February and March, the oxygen level in the bag incubations remained constant, validating the low balanced heterotrophic and autotrophic activity. As the autotrophic activity exceeded the heterotrophic activity in late March and April, it resulted in a significant net oxygen accumulation in the bag incubations. Integrated over the entire season, the sea ice of Malene Bight was net autotrophic with an annual net carbon fixation of $220 \mathrm{mg} \mathrm{C} \mathrm{m}^{-2}$, reflecting the net result of a sea ice-related gross primary production of $350 \mathrm{mg} \mathrm{C} \mathrm{m}^{-2}$ and concurrent bacterial carbon demand of $130 \mathrm{mg} \mathrm{C} \mathrm{m}^{-2}$. Converting the $\mathrm{O}_{2}$ net exchange of the bag incubations into carbon turnover estimated an annual net carbon fixation of $1700 \pm 760 \mathrm{mg} \mathrm{C} \mathrm{m}^{-2}$ (mean $\pm \mathrm{SD}$ ), which was higher than the annual net carbon fixation quantified in the standard incubations.
\end{abstract}

KEY WORDS: Sea ice $\cdot$ Primary production $\cdot$ Bacterial carbon demand $\cdot$ Net autotrophic activity Net heterotrophic activity · Attenuation coefficients

\section{INTRODUCTION}

Sea ice provides a low-temperature habitat for diverse communities of microorganisms including viruses, bacteria and heterotrophic (e.g. flagellates and ciliates) and autotrophic protists (e.g. diatoms) (Kaartokallio et al. 2006). During sea ice formation, microorganisms, inorganic solutes and solids can be incorporated into the ice and accumulate to concentrations higher than that in the underlying seawater (Reimnitz et al. 1992, Grossmann \& Gleitz 1993, Gradinger \& Ikävalko 1998). Organisms incorporated into sea ice are challenged with changes in space, light availability, salinity, nutrients, dissolved inorganic carbon (DIC) and $\mathrm{O}_{2}$ concentration, temperature and $\mathrm{pH}$ (Gradinger \& Ikävalko 1998) Especially, light availability within the sea ice has a major influence on the sea ice algal biomass and production (Cota \& Horne 1989, Rysgaard et al. 2001).

Sea ice algae constitute an important component of sympagic communities and have been extensively studied in Arctic sea ice (e.g. Horner \& Schrader 1982, Gosselin et al. 1997, Glud et al. 2007, Mikkelsen et al. 2008). The sea ice algae represent an important food source for metazoan grazers, and photosynthetic prod- 
ucts or entrained organic material can lead to elevated bacteria abundance and production within the sea ice (Smith et al. 1989, Krembs et al. 2002, Meiners et al. 2003, Riedel et al. 2007).

Several previous studies have shown that heterotrophic bacteria are active and abundant in Arctic sea ice (Bunch \& Harland 1990, Smith \& Clement 1990, Brinkmeyer et al. 2003, Lizotte 2003, Kaartokallio 2004), but studies on spatial and seasonal variations are few (Smith et al. 1989, Gradinger and Zhang 1997).

Sea ice represents a partially interconnected network of brine-filled channels comprising 1 to $30 \%$ of the sea ice volume (e.g. Weeks \& Ackley 1986). The degree of interconnection of the brine enclosures is generally enhanced with increasing temperature, and the potential accumulation of sea ice algae therefore increases towards the polar spring. The significance of heterotrophic processes typically increases during late bloom and postbloom situations close to spring thaw (Vézina et al. 1997, Kaartokallio 2004). In addition to biologically mediated dynamics, thaw and freezing processes induce extensive dynamics in solute and gas distribution (Glud et al. 2002). Consequently, the sea ice matrix is highly heterogeneous and dynamic, and quantification of in situ algae and bacterial productivity represent a true challenge.

The overall objective of this investigation was to describe the dynamics of autotrophic and heterotrophic activity in first-year sea ice. We measured autotrophic and heterotrophic activity of intact sea ice cores under in situ conditions in bag incubations, and measurements were compared with primary production and bacterial carbon demand as measured in the laboratory by standard $\mathrm{H}^{14} \mathrm{CO}_{3}{ }^{-}$and $\left[{ }^{3} \mathrm{H}\right]$ thymidine incubations under well-defined conditions.

\section{MATERIALS AND METHODS}

Measurements were conducted on first-year landfast sea ice in Malene Bight in the vicinity of Nuuk, SW Greenland $\left(64^{\circ} 82^{\prime} \mathrm{N}, 51^{\circ} 42^{\prime} \mathrm{W}\right)$. Sampling was performed at 1 to 2 wk intervals from 1 February to 14 April 2008. During that period, sea ice thickness varied between 0 and $62 \mathrm{~cm}$, while snow cover ranged between 0 and $28 \mathrm{~cm}$. The net aerobic activity of an enclosed sea ice community was followed in situ by determining the $\mathrm{O}_{2}$ concentrations in sea ice cores sealed in plastic bags and placed under natural snow cover, hereafter referred to as 'bag incubations'. These measurements were supplemented with standard measurements of temperature, salinity, irradiance attenuation in snow and ice, nutrient concentrations (phosphate, $\mathrm{PO}_{4}{ }^{3-}$; nitrate and nitrite, $\mathrm{NO}_{3}{ }^{-}+\mathrm{NO}_{2}{ }^{-}$; silicic acid, $\mathrm{Si}(\mathrm{OH})_{4}$; and ammonium, $\left.\mathrm{NH}_{4}{ }^{+}\right)$, chlorophyll a (chl a) concentrations, sea ice algal productivity and bacterial carbon demand during each sampling campaign, the latter 2 being referred to as 'standard incubations'.

On 15 February and 19 March, 10 sea ice cores were collected using a MARK II coring system (Kovacs Enterprises). Cores were cut into 2 sections of equal length (ca. $22 \mathrm{~cm}$ ), i.e. top half and bottom half, which were brought back to the laboratory in black plastic bags within $1 \mathrm{~h}$ of sampling. In a laboratory cold room $(3 \pm$ $1^{\circ} \mathrm{C}$ ), core sections were placed in laminated transparent NEN/PE plastic bags (Hansen et al. 2000) fitted with a gas-tight Tygon tube and a valve for sampling.

Artificial seawater (salinity of 33) with a known $\mathrm{O}_{2}$ concentration was added (10 to $30 \mathrm{ml}$ ) to the NEN/PE bags (Hansen et al. 2000). The bags were closed, and excess air quickly extracted through the valve. The top and bottom halves of a single ice core (i.e. the contents of one pair of bags) were melted within $48 \mathrm{~h}$ in darkness $\left(3 \pm 1^{\circ} \mathrm{C}\right)$. Gas bubbles released from the melting sea ice were subsequently transferred to $12 \mathrm{ml}$ Exetainer tubes (Labco) containing $20 \mu \mathrm{HgCl}_{2}(5 \% \mathrm{w} / \mathrm{v}$, saturated solution). The gas bubbles were analysed for gaseous $\mathrm{O}_{2}$ by gas chromatography in a flame ionization detector and thermal conductivity detector (FID/TCD, SRI model 8610C). The melted water was also transferred to Exetainer tubes for $\mathrm{O}_{2}$ measurements. Dissolved $\mathrm{O}_{2}$ in the melted sea ice was measured by Winkler titration (Grasshoff et al. 1983). The remaining 9 sea ice cores in plastic bags were transferred to the drilled holes at the sea ice sampling site within $2 \mathrm{~h}$, and the in situ snow cover above the cores was re-established. The sea ice cores, i.e. top and bottom halves, were sampled at 1 to $2 \mathrm{wk}$ intervals to determine the $\mathrm{O}_{2}$ bulk concentration of the sea ice.

Permeability of the NEN/PE bags was quantified by adding artificial seawater (salinity of 33) to 9 plastic bags containing a gas-tight valve for sampling (Hansen et al. 2000). The bags were spiked with $\mathrm{HgCl}_{2}$ ( $200 \mu \mathrm{l}$ of a $5 \%$ solution per liter seawater) to prevent biological activity during the incubation. The water was then flushed with $\mathrm{N}_{2}$ gas until the $\mathrm{O}_{2}$ concentration in the bags reached $50 \%$ of atmospheric saturation. The valves in the bags were then closed ensuring that no gas phase was left inside the $1 \mathrm{l}$ bag. Three bags were incubated at $-20^{\circ} \mathrm{C}, 3$ bags at $3^{\circ} \mathrm{C}$ and 3 bags at $20^{\circ} \mathrm{C}$ for $7 \mathrm{~d}$. Initially the $\mathrm{O}_{2}$ concentration was measured in all bags. After the incubation, $\mathrm{O}_{2}$ samples were collected and measured as described previously. Ice formation in the bags $\left(-20^{\circ} \mathrm{C}\right.$ experiment) led to bubble formation and the $\mathrm{O}_{2}$ concentration was therefore calculated as the sum of $\mathrm{O}_{2}$ in gas and water. The maximum $\mathrm{O}_{2}$ flux across the plastic bags was calculated from the $\mathrm{O}_{2}$ concentration change between initial and final readings to $0.48 \pm 0.20 \mu \mathrm{mol} \mathrm{O} \mathrm{l}_{2} \mathrm{l}^{-1} \mathrm{~d}^{-1}$ (mean $\pm \mathrm{SD}$ ). This put a lower limit on the activity that can be 
resolved by this procedure and may compromise overall net activity at low biomass. In reality the permeability at the incubation temperature $\left(-5\right.$ to $\left.0^{\circ} \mathrm{C}\right)$ was significantly less than our maximum value.

$\mathrm{O}_{2}$ bulk concentration in the sea ice $\left(C_{\mathrm{i}}\right)$ was calculated as:

$$
C_{\mathrm{i}}=\frac{\left(C_{\mathrm{m}} \times W_{\mathrm{m}}\right)-\left(C_{\mathrm{a}} \times W_{\mathrm{a}}\right)}{W_{\mathrm{i}}}
$$

where $C_{\mathrm{m}}$ is the $\mathrm{O}_{2}$ concentration in the melted sea ice (gas bubble + melted sea ice), $W_{\mathrm{m}}$ is the weight of the melted sea ice, $C_{a}$, is the $\mathrm{O}_{2}$ concentration in the artificial sea water, $W_{\mathrm{a}}$ is the weight of the artificial sea water, and $W_{\mathrm{i}}$ is the weight of the sea ice (Rysgaard \& Glud 2004).

The season was divided into Series 1 and Series 2 . Series 1 consisted of 10 cores, which were incubated on 15 February and were individually collected for analysis from 15 February to 25 March. Series 2 consisted of another 10 cores incubated on 19 March and were individually collected for analysis from 19 March to 11 April. Linear regression was performed on each of the 4 series (i.e. top half and bottom half of cores in Series 1 and Series 2). The slope of the regression line was tested in all 4 series by means of Student's $t$-test.

On each of the 7 sampling occasions, triplicate ice cores were collected using a MARK II coring system. The 3 sea ice cores were cut into sections using a stainless steel handsaw, and vertical temperature profiles were measured in drilled holes to the centre of each section using a thermometer (Testo thermometer). Downwelling irradiance was measured directly above and below the snow with a data logger (LI-1400, Li-Cor Biosciences). In addition, air temperature was measured $2 \mathrm{~m}$ above the snow, and snow and sea ice thicknesses were determined using a measuring stick. The sea ice sections were placed in plastic containers in a dark insulated transport box (Thermobox) and brought back to the laboratory. Light attenuation of the sea ice samples was measured with a LI-1400 data logger in a dark thermally regulated room using a fibre lamp with a spectrum close to natural sunlight $(15 \mathrm{~V}, 150 \mathrm{~W}$, fibreoptic tungsten-halogen bulb). The LI-1400 data logger was placed under the sea ice section and the fibre lamp was placed above. Light attenuation was measured this way for each sea ice section. All sea ice samples were melted within $48 \mathrm{~h}$ for analysis of nutrients, salinity, chl $a$, primary production and bacterial carbon demand analysis at $3 \pm 1^{\circ} \mathrm{C}$ in darkness.

The melted sea ice was filtered onto $25 \mathrm{~mm} \mathrm{GF/F}$ filters (Whatman) for chl a analysis. The filters were extracted for $18 \mathrm{~h}$ in $96 \%$ ethanol (Jespersen \& Christoffersen 1987) and analysed fluorometrically (Turner TD700 fluorometer, Turner Designs) before and after addition of $200 \mu \mathrm{l}$ of a $1 \mathrm{M} \mathrm{HCl}$ solution. The fluorometer was calibrated against a pure chl a standard
(Turner Designs). The remaining filtered sea ice was frozen $\left(-18^{\circ} \mathrm{C}\right)$ for later analysis of $\mathrm{PO}_{4}{ }^{3-}, \mathrm{NO}_{3}{ }^{-}+\mathrm{NO}_{2}{ }^{-}$, $\mathrm{Si}(\mathrm{OH})_{4}$ and $\mathrm{NH}_{4}{ }^{+}$. Concentrations of $\mathrm{NO}_{3}{ }^{-}+\mathrm{NO}_{2}{ }^{-}$were measured by vanadium chloride reduction (Braman \& Hendrix 1989). Concentrations of $\mathrm{Si}(\mathrm{OH})_{4}$ and $\mathrm{PO}_{4}{ }^{3-}$ were determined by spectrophotometric analysis (Strickland \& Parsons 1972, Grasshoff et al. 1983). Concentrations of $\mathrm{NH}_{4}{ }^{+}$were determined by a fluorometric method (Holmes et al. 1999). The lower detection limit for the nutrient measurements were $0.002 \mu_{\mathrm{mol} \mathrm{l}}^{-1}$ for $\mathrm{PO}_{4}{ }^{3-}, 0.5 \mathrm{mmol} \mathrm{l}^{-1}$ for $\mathrm{NO}_{3}^{-}+\mathrm{NO}_{2}{ }^{-}, 0.002 \mu \mathrm{mol} \mathrm{l}{ }^{-1}$ for $\mathrm{Si}(\mathrm{OH})_{4}$ and $0.10 \mu \mathrm{mol} \mathrm{l} \mathrm{l}^{-1}$ for $\mathrm{NH}_{4}{ }^{+}$(lower detection limit is calculated using the $t$-value of 2.99 corresponding to a $99 \%$ confidence interval with $\mathrm{df}=7$ ). Conductivity of the melted sea ice sections was measured using a conductivity cell (Thermo Orion 3-star with an Orion 013610MD conductivity cell) and converted to bulk salinity (Grasshoff et al. 1983). Sea ice brine salinity was calculated as a function of temperature (Cox \& Weeks 1983) and the brine volume as a function of bulk salinity, density and temperature. Brine volume was calculated according to Leppäranta \& Manninen (1988) for temperatures greater than $-2^{\circ} \mathrm{C}$ and according to Cox \& Weeks (1983) for temperatures less than $-2^{\circ} \mathrm{C}$.

Primary production was determined in melted (melted within $48 \mathrm{~h}$ in dark conditions at $3 \pm 1^{\circ} \mathrm{C}$ ) sea ice water at 3 light intensities $(42,21$ and $9 \mu \mathrm{mol}$ photons $\mathrm{m}^{-2} \mathrm{~s}^{-1}$ ) and corrected with one dark incubation using the $\mathrm{H}^{14} \mathrm{CO}_{3}^{-}$incubation technique (SteemanNielsen 1952). The sea ice samples were melted and subsequently acclimatised at $20 \mu \mathrm{mol}$ photons $\mathrm{m}^{-2} \mathrm{~s}^{-1}$ for a few hours $(>2 \mathrm{~h})$. Then the sea ice samples were poured into $120 \mathrm{ml}$ gastight glass bottles and $4 \mu \mathrm{Ci}$ of $\mathrm{H}^{14} \mathrm{CO}_{3}{ }^{-}$were added to each bottle. The bottles were incubated on a plankton wheel at $1 \mathrm{rpm}$ for $5 \mathrm{~h}$ at $3 \pm$ $1^{\circ} \mathrm{C}$ at the different light intensities. Illumination was provided by cool white fluorescent lamps with a spectrum close to natural sunlight (Master TL-D 36W/840, Phillips) and irradiance was measured using a LI-1400 data logger. Incubations were terminated by adding $200 \mu \mathrm{l}$ of $5 \% \mathrm{ZnCl}_{2}$ and subsequently filtered onto $25 \mathrm{~mm}$ GF/F filters (Whatman). The filters were placed in scintillation vials containing $200 \mu \mathrm{l} 1 \mathrm{M} \mathrm{HCl}$ to remove labelled, unfixed inorganic carbon, and then extracted in scintillation liquid (PerkinElmer Ultima Gold) for $22 \mathrm{~h}$ and counted using a liquid scintillation analyser (TricCarb 2800 TR, PerkinElmer). Dissolved inorganic carbon (DIC) concentrations in melted sea ice were measured on a $\mathrm{CO}_{2}$ coulometer as described by Rysgaard \& Glud (2004). After liquid scintillation counting, counts were converted to potential primary production

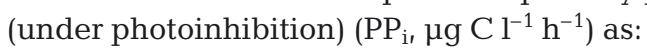

$$
\mathrm{PP}_{\mathrm{i}}=\frac{\mathrm{DPM}_{\text {activity }} \times \mathrm{DIC}_{\text {sea ice }} \times \mathrm{F}_{\text {discr }} \times \mathrm{M}_{\mathrm{c}}}{\mathrm{DPM} \mathrm{M}_{\text {added }} \times \mathrm{t}_{\text {inc }}}
$$


where $\mathrm{DPM}_{\text {activity }}$ is the ${ }^{14} \mathrm{C}$ assimilated carbon corrected for assimilated carbon in the dark (disintegrations per minute $[\mathrm{dpm}]$ on filter), $\mathrm{DIC}_{\text {sea ice }}$ is dissolved inorganic carbon in melted sea ice $(\sim 450 \mu \mathrm{mol}$ $\left.\mathrm{l}^{-1}\right), \mathrm{F}_{\text {discr }}=1.05$ is the discrimination factor of algae assimilation of ${ }^{12} \mathrm{CO}_{2}$ and ${ }^{14} \mathrm{CO}_{2}, \mathrm{M}_{\mathrm{c}}$ is the molar mass of carbon $\left(12.01 \mathrm{~g} \mathrm{~mol}^{-1}\right), \mathrm{DPM}_{\text {added }}$ is the specific activity of the ${ }^{14} \mathrm{C}$ labelled medium ( $\left.\mathrm{dpm} \mathrm{ml}^{-1}\right)$ in which cells were labelled, and $t_{\text {inc }}$ is the incubation time $(5 \mathrm{~h})$.

The potential primary production (under no photoinhibition) ( $\mathrm{PP}, \mu \mathrm{C} \mathrm{Cl}^{-1} \mathrm{~h}^{-1}$ ) measured in the laboratory at different sea ice depths was plotted against the 3 laboratory light intensities, 42, 21 and $9 \mu \mathrm{mol}$ photons $\mathrm{m}^{-2} \mathrm{~s}^{-1}$, and fitted to the following function described by Platt et al. (1980):

$$
\mathrm{PP}=P_{\mathrm{m}}\left[1-\exp \left(\frac{-\alpha E_{\mathrm{PAR}}}{P_{\mathrm{m}}}\right)\right]
$$

where $P_{\mathrm{m}}\left(\mu \mathrm{g} \mathrm{C}^{-1} \mathrm{~h}^{-1}\right)$ is the maximum photosynthetic rate at light saturation, $\alpha\left(\mu \mathrm{g} \mathrm{C} \mathrm{m}{ }^{2} \mathrm{~s} \mu \mathrm{mol}\right.$ photons ${ }^{-1} \mathrm{l}^{-1}$ $\left.\mathrm{h}^{-1}\right)$ is the initial slope of the light curve and $E_{\mathrm{PAR}}(\mu \mathrm{mol}$ photons $\mathrm{m}^{-2} \mathrm{~s}^{-1}$ ) is the laboratory irradiance. The photoadaptation index, $E_{\mathrm{k}}\left(\mu \mathrm{mol}\right.$ photons $\mathrm{m}^{-2} \mathrm{~s}^{-1}$ ) was calculated as $P_{\mathrm{m}} / \alpha$.

In situ downwelling irradiance was measured at ground level with a pyrometer (Kipp \& Zonen, model CM21, spectrum range of 305 to $2800 \mathrm{~nm}$ ) once every 5 min, and hourly averages were provided by Asiaq (Greenland Survey). Hourly downwelling irradiance was converted into hourly photosynthetically active radiation (PAR) (light spectrum, 300 to $700 \mathrm{~nm}$ ) after intercalibration $\left(\mathrm{r}^{2}=0.99, \mathrm{p}<0.001, \mathrm{n}=133\right)$ with a LI1400 data logger (Li-Cor). The in situ hourly PAR irradiance was calculated at different depths, depending on sea ice and snow thickness, using the attenuation coefficients measured during the sea ice season.

In situ primary production was calculated for each hour at different sea ice depths using hourly in situ PAR irradiance (see Eq. 3). Total daily ( $24 \mathrm{~h}$ ) in situ primary production was calculated as the sum of hourly in situ primary production for each depth. The depthintegrated net primary production was calculated using trapezoid integration.

Bacteria production in melted sea ice samples was determined by measuring the incorporation of $\left[{ }^{3} \mathrm{H}\right]$ thymidine into DNA. Triplicate subsamples (volume, $V_{\text {filt }}=0.01 \mathrm{l}$ ) were incubated in darkness at $3 \pm$ $1^{\circ} \mathrm{C}$ with $10 \mathrm{nM}$ of labelled $\left[{ }^{3} \mathrm{H}\right]$ thymidine (New England Nuclear, specific activity, $10.1 \mathrm{Ci} \mathrm{mmol}^{-1}$ ). Trichloroacetic acid (TCA)-killed controls were made to measure the abiotic adsorption. At the end of the incubation period $\left(t_{\text {inc }}=6 \mathrm{~h}\right), 1 \mathrm{ml}$ of $50 \%$ cold TCA was added to all the subsamples (Fuhrman \& Azam 1982). Subsamples of $\left[{ }^{3} \mathrm{H}\right]$ thymidine were stored at $3 \pm 1^{\circ} \mathrm{C}$ in scintillations vials until filtration. Subsamples were fil- trated through $25 \mathrm{~mm}$ mixed cellulose ester filters (pore size $0.2 \mu \mathrm{m}$, Advantec MSF) and the filters were placed in scintillation vials. Scintillation vials were rinsed with $5 \mathrm{ml}$ of $5 \%$ cold TCA. Subsequently, filters were rinsed 7 times with $1 \mathrm{ml}$ of cold $5 \%$ TCA and then extracted in scintillation liquid (Ultima Gold, PerkinElmer) for $22 \mathrm{~h}$ and counted using a liquid scintillation analyser (TricCarb 2800, PerkinElmer).

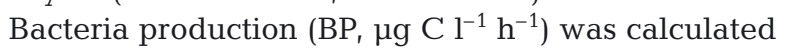
as:

$$
\mathrm{BP}=\frac{\mathrm{DPM}_{\text {sample }} \times \mathrm{N}_{\text {cells }} \times \mathrm{N}_{\mathrm{c}} \times \mathrm{M}_{\mathrm{c}}}{\mathrm{SA} \times \mathrm{t}_{\text {inc }} \times \mathrm{V}_{\text {fill }}}
$$

where DPM $\mathrm{Dample}_{\text {is }}$ is the average dpm for the live treatment subtracted from the average dpm for the TCAkilled controls, $\mathrm{N}_{\text {cells }}$ is the conversion factor $(2.09 \times$ $10^{18}$ cells $\mathrm{mol}^{-1}{ }^{3} \mathrm{H}$, according to Smith \& Clement $1990), t_{\text {inc }}$ is the incubation period ( $\left.t_{\text {inc }}=6 \mathrm{~h}\right), V_{\text {filt }}$ is the volume of the subsamples $\left(V_{\text {filt }}=0.01 \mathrm{l}\right), \mathrm{M}_{\mathrm{c}}$ is the molecular mass of carbon and SA is the specific activity of the thymidine solution $\left(2.24 \times 10^{16} \mathrm{dpm} \mathrm{mol}^{-1}\right)$.

$\mathrm{N}_{\mathrm{c}}=5.7 \times 10^{-8} \mu \mathrm{g} \mathrm{C}$ cell $^{-1}$ is calculated as:

$$
\mathrm{N}_{\mathrm{c}}=\frac{\text { Cell }_{\text {size }} \times C_{\text {factor }}}{1000000}
$$

where Cell ${ }_{\text {size }}$ is the average bacteria cell size $\left(0.473 \mu \mathrm{m}^{3}\right)$ (Smith \& Clement 1990), and $C_{\text {factor }}$ is the factor used

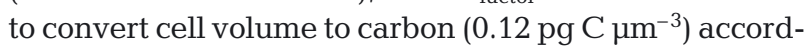
ing to Smith \& Clement (1990).

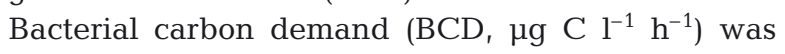
calculated as:

$$
\mathrm{BCD}=\frac{\mathrm{BP}}{\mathrm{BGE}}
$$

where $\mathrm{BP}$ is the bacteria production and BGE is the bacterial growth efficiency of 0.5 according to Rivkin \& Legendre (2001). To extrapolate bacterial carbon demand to daily in situ carbon demand we assumed that the respiration was light-independent (multiply by 24). The depth-integrated bacterial carbon demand was calculated using trapezoid integration.

On 23 February, 10 sea ice cores were collected along a $10 \mathrm{~m}$ long section to investigate the spatial (horizontal and vertical) variability of the biotic conditions ( $\mathrm{chl} a_{\text {, }}$ primary production and bacterial carbon demand) and the abiotic conditions (sea ice temperature, bulk salinity and brine volume) in the sea ice. The 10 sea ice cores were collected close to the plastic bag incubations at $1 \mathrm{~m}$ intervals. The cores were cut into 2 sections, i.e. top and bottom halves, and brought back to the laboratory in a dark Thermobox for further analysis as described.

To extend the evaluation of spatial variability, a large-scale investigation of horizontal variability was conducted on 29 February. Fifty-two sea ice cores were collected along a $367 \mathrm{~m}$ long transect to investigate the 
heterogeneity of chl $a$, sea ice temperature, brine salinity and brine volume in the bottom of the sea ice. The snow and sea ice thickness was measured as described previously. Four sea ice cores were sampled at $20 \mathrm{~cm}$ intervals at position $1 \mathrm{~m}$. The first core was cut vertically into 2 pieces at every sampling position. Sea ice cores were collected at distances of $1,3,5,7,9,20,31$, 42, 53, 64, 165, 266 and ca. $367 \mathrm{~m}$. All the ice cores were brought back to the laboratory in a dark Thermo box for determination of brine salinity, volume and chl a concentration as described.

Spatial autocorrelation (Legendre \& Legendre 1998) was used to analyse the horizontal distribution of chl $a$, sea ice temperature, bulk salinity, snow thickness and sea ice thickness. We assume that the variability along one line is the same as along a perpendicular line. The autocorrelation was estimated by Moran's I coefficients (Moran 1950, Legendre \& Legendre 1998). This coefficient was calculated for each of the following intervals along the transect (distance classes): 0 to

a) Sea ice and snow temperature $\left({ }^{\circ} \mathrm{C}\right)$

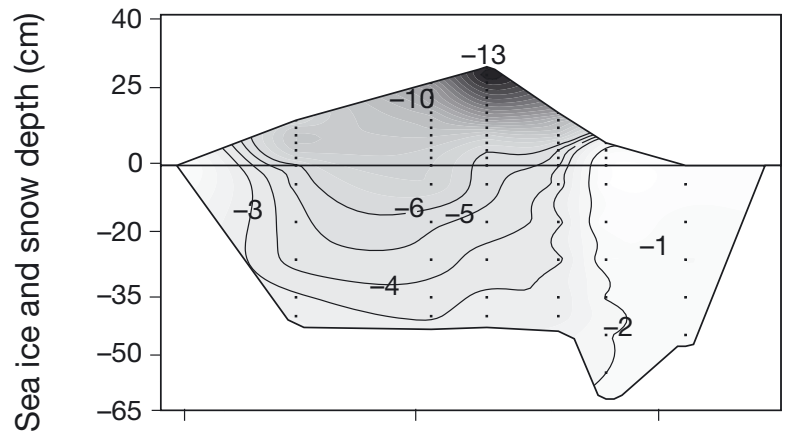

b) Light attenuation coefficient $\left(\mathrm{m}^{-1}\right)$

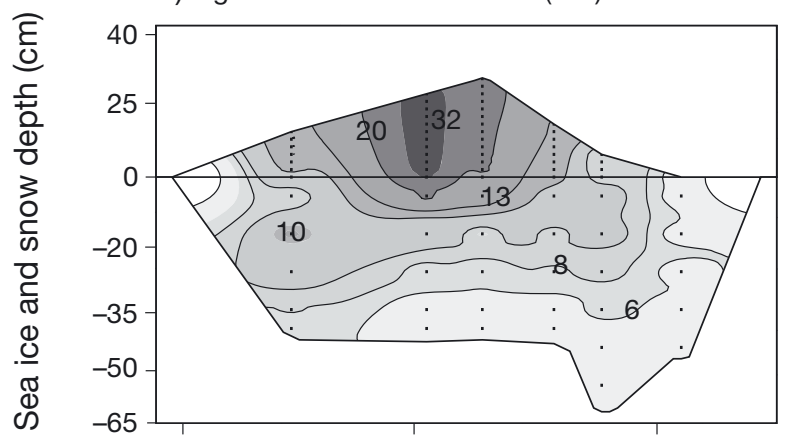

c) Irradiance ( $\mu \mathrm{mol}$ photons $\mathrm{m}^{-2} \mathrm{~s}^{-1}$ )

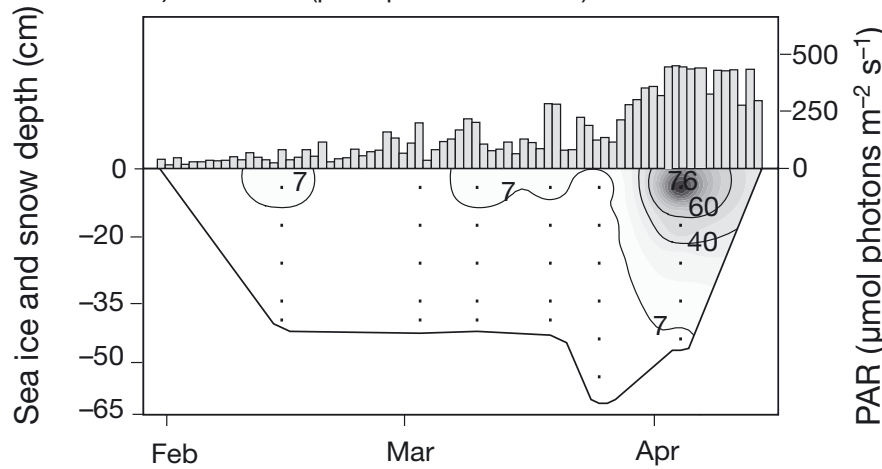

$0.50 \mathrm{~m}, 0.50$ to $1.5 \mathrm{~m}, 1.5$ to $2.5 \mathrm{~m}, 2.5$ to $5.5 \mathrm{~m}, 5.5$ to $10.5 \mathrm{~m}, 10.5$ to $20.5 \mathrm{~m}, 20.5$ to $50.5 \mathrm{~m}, 50.5$ to $100.5 \mathrm{~m}$ and $>100.5 \mathrm{~m}$. The autocorrelation coefficients estimated by Moran's I coefficient were tested for significance according to the method described in Legendre \& Legendre (1998). A 2-tailed test of significance was used. The null hypothesis of random spatial distribution was rejected at the specified level of significance when an individual autocorrelation coefficient exceeded a critical value (positive or negative). A significance level of $\mathrm{p}<0.05$ was used.

\section{RESULTS}

\section{Abiotic parameters}

Temperatures within the snow cover varied from -13 to $0^{\circ} \mathrm{C}$ and the sea ice temperature from -5 to $0^{\circ} \mathrm{C}$ (Fig. 1a). Minimum temperatures of the sea ice were

d) Bulk salinity

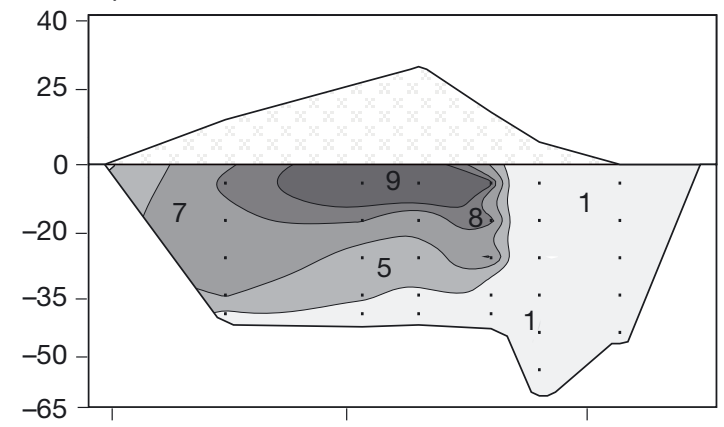

e) Relative brine volume (\%)

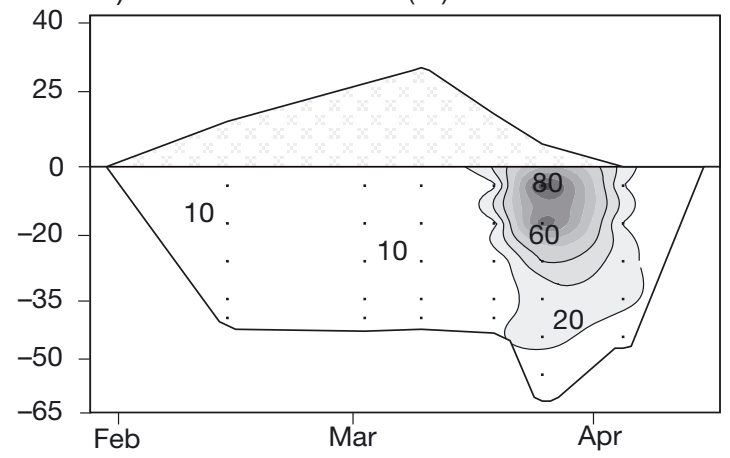

Fig. 1. Sea ice development in Malene Bight, NW Greenland, during the 2008 season: (a) sea ice and snow temperature $\left({ }^{\circ} \mathrm{C}\right)$, (b) light attenuation coefficient $\left(\mathrm{m}^{-1}\right),(\mathrm{c})$ average daily photon irradiance in sea ice and at surface (PAR, $\mu \mathrm{mol}$ photons $\mathrm{m}^{-2} \mathrm{~s}^{-1}$ ), (d) bulk salinity, (e) relative brine volume fraction (\%). The sea ice in late March from 0 to $16 \mathrm{~cm}$ is a layer of granular snow-ice. The black dots represent triplicate measurements 
observed in February, after which the temperature gradually increased to maximum values just before sea ice break-up in mid-April. The high light reflectance and scatter from the snow cover caused strong light attenuation throughout the sea ice season, with average attenuation coefficients of $K_{\text {snow }}=23 \mathrm{~m}^{-1}$ and $K_{\text {ice }}=$ $8 \mathrm{~m}^{-1}$ (Fig. 1b). Early in the sea ice season, irradiance at the bottom of the sea ice was low (0.03 to $0.15 \mu \mathrm{mol}$ photons $\mathrm{m}^{-2} \mathrm{~s}^{-1}$ ) (Fig. 1c). Light availability increased along with increasing day length and declining snow cover, reaching a maximum downwelling irradiance of $76 \mu \mathrm{mol}$ photons $\mathrm{m}^{-2} \mathrm{~s}^{-1}$ in the uppermost sea ice section and $7 \mu \mathrm{mol}$ photons $\mathrm{m}^{-2} \mathrm{~s}^{-1}$ in the bottom on April 4.

The bulk salinity decreased over time with a maximum salinity of 9 in early March and a minimum salinity of 1 from late March and onward (Fig. 1d). Bulk salinity varied vertically within sea ice cores during winter, with lower values encountered in the bottom sea ice from mid-February until late March. From 25 March to 4 April, bulk salinity was lowest in the uppermost part of the sea ice. The relative brine volume increased throughout the sea ice season, with a maximum in late March in the uppermost section of

a) Phosphate $\left(\mu \mathrm{mol} \mathrm{I} \mathrm{I}^{-1}\right)$

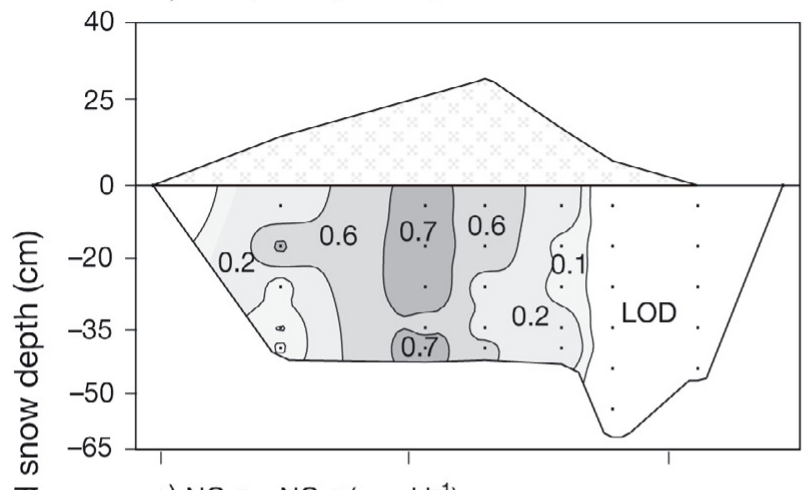

c) $\mathrm{NO}_{3}^{-}+\mathrm{NO}_{2}^{-}\left(\mu \mathrm{mol} \mathrm{I}^{-1}\right)$

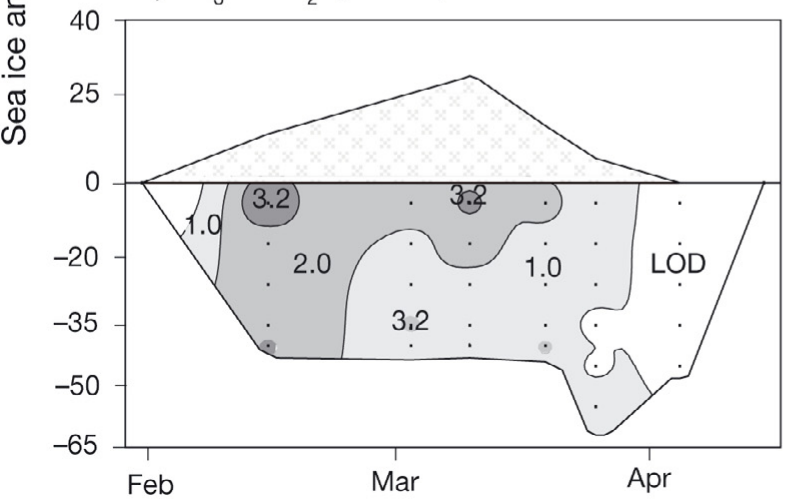

the sea ice (Fig. 1e). In late March melting from the top of the sea ice was initiated, which resulted in high relative brine volumes and low bulk salinities in the uppermost part of the sea ice. During this period air temperatures varied between 0 and $7^{\circ} \mathrm{C}$.

\section{Nutrient parameters}

Bulk $\mathrm{PO}_{4}{ }^{3-}$ concentration was initially 0.05 to $0.20 \mu \mathrm{mol} \mathrm{l}^{-1}$ (Fig. 2a), and increased to a maximum of $0.70 \mu \mathrm{mol} \mathrm{l}^{-1}$ in March but subsequently decreased to $0.05 \mu \mathrm{mol} \mathrm{l^{-1 }}$ in April. Bulk $\mathrm{Si}(\mathrm{OH})_{4}$ concentration remained constant between 1.8 and $2.3 \mu \mathrm{mol} \mathrm{l^{-1 }}$ in the sea ice from February to late March with lowest values encountered at the bottom of the sea ice. In late March, $\mathrm{Si}(\mathrm{OH})_{4}$ concentration decreased rapidly to below $0.4 \mathrm{mmol} \mathrm{l}^{-1}$ (Fig. 2b). The initial bulk concentration of $\mathrm{NO}_{3}{ }^{-}+\mathrm{NO}_{2}{ }^{-}$was $3.2 \mu \mathrm{mol} l^{-1}$ at the top and $2.0 \mu \mathrm{mol} \mathrm{l} \mathrm{l}^{-1}$ at the bottom of the sea ice (Fig. 2c) and decreased throughout the season, reaching a minimum of $0.5 \mu \mathrm{mol} \mathrm{l}^{-1}$ in April. The initial bulk concentration of $\mathrm{NH}_{4}{ }^{+}$was $4.0 \mu \mathrm{mol} \mathrm{l} \mathrm{l}^{-1}$ at the top and bottom of the sea ice. During the sea ice season the $\mathrm{NH}_{4}{ }^{+}$concentration

b) Silicic acid $\left(\mu \mathrm{mol} \mathrm{I}^{-1}\right)$

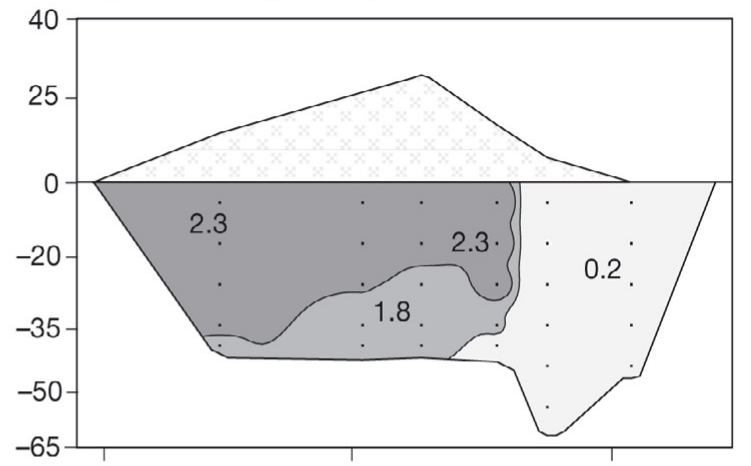

d) Ammonium ( $\left.\mu \mathrm{mol} \mathrm{I}^{-1}\right)$

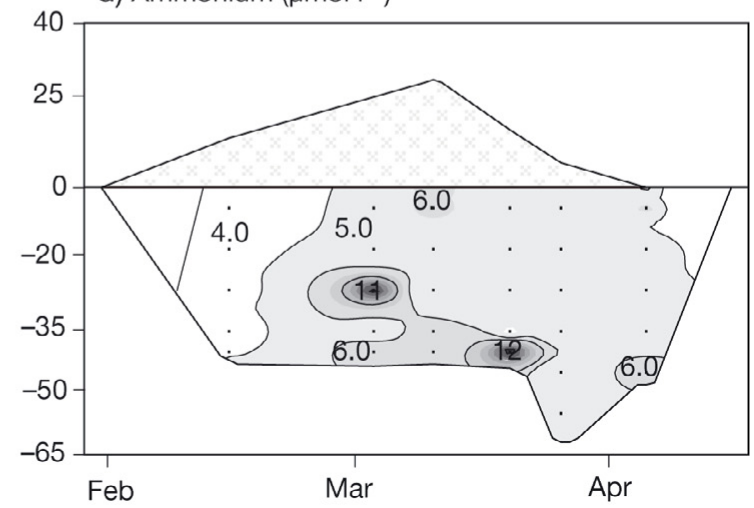

Fig. 2. Nutrient concentration $\left(\mu \mathrm{mol} \mathrm{l} \mathrm{l}^{-1}\right.$ ) in bulk sea ice: (a) phosphate, (b) silicic acid, (c) $\mathrm{NO}_{3}{ }^{-}+\mathrm{NO}_{2}{ }^{-}$, (d) ammonium. LOD is lower limit of detection, which is calculated using the $t$-value of 2.99 corresponding to a $99 \%$ confidence interval with $\mathrm{df}=7$. The black dots represent triplicate measurements 
a) Phosphate

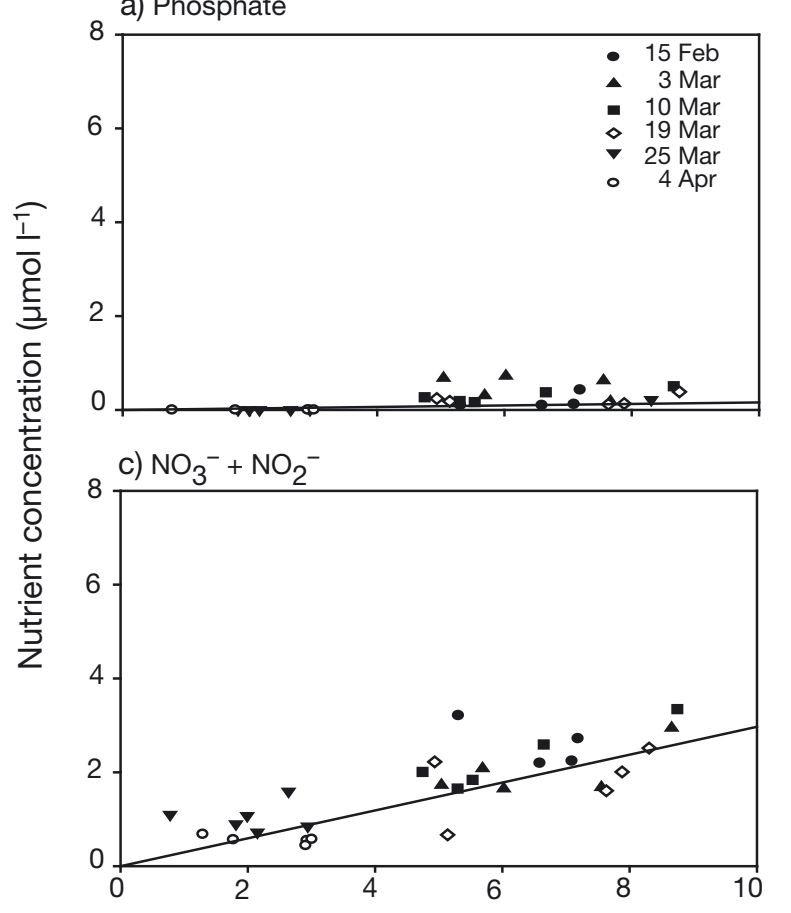

b) Silicic acid
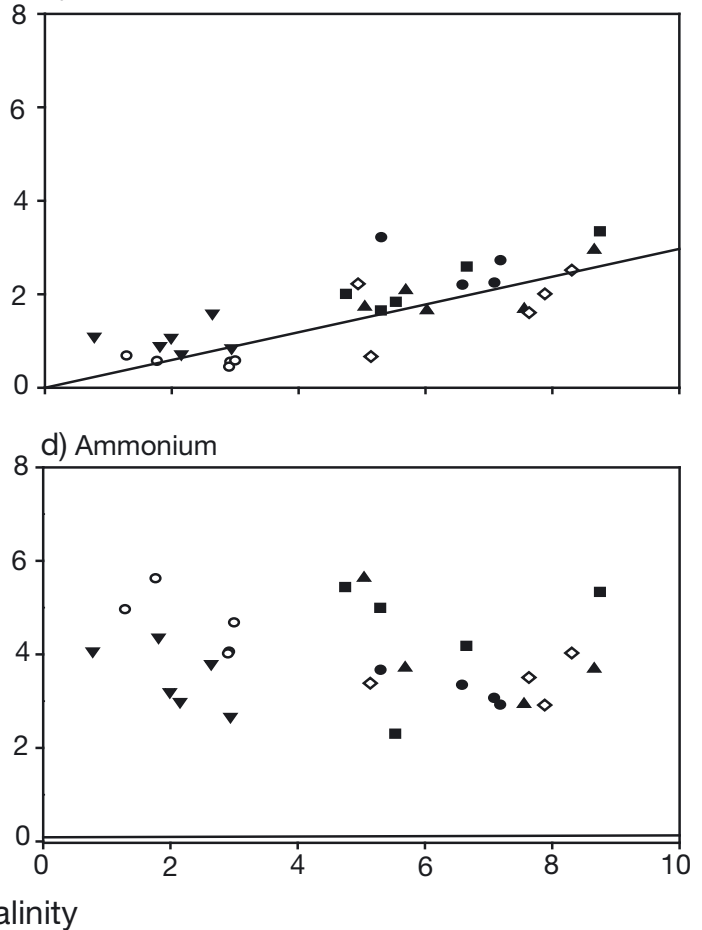

Fig. 3. Concentrations of (a) phosphate, (b) silicic acid, (c) $\mathrm{NO}_{3}{ }^{-}+\mathrm{NO}_{2}{ }^{-}$and (d) ammonium versus bulk salinity in sea ice. The solid line indicates the expected dilution line predicted from salinity and nutrient concentrations in seawater $(0$ to $10 \mathrm{~m}$ depth, salinity of 33). See 'Results: Nutrient parameters' for explanation

increased, reaching values of 6 to $12 \mu \mathrm{mol} \mathrm{l}^{-1}$ at the bottom of the sea ice and 5.0 to $6.0 \mu \mathrm{mol} \mathrm{l}^{-1}$ at the top of the sea ice (Fig. 2d).

Bulk nutrient concentrations for each sampling date were plotted as a function of bulk salinity and compared with the expected dilution line (according to Clarke \& Ackley 1984). If values were below the line, depletion of nutrients occurred in the sea ice. If values were above the dilution line, production or net deposition of the solute took place. Plots of salinity$\mathrm{PO}_{4}{ }^{3-}$, salinity- $\mathrm{Si}(\mathrm{OH})_{4}$, salinity- $\mathrm{NO}_{3}{ }^{-}+\mathrm{NO}_{2}{ }^{-}$and salinity- $\mathrm{NH}_{4}{ }^{+}$in sea ice were generally all above the dilution line (Fig. 3), but most explicitly for $\mathrm{NH}_{4}{ }^{+}$, which clearly accumulated within the sea ice (Fig. 3d).

\section{Biotic parameters}

Sea ice profiles of the algal biomass, expressed as chl $a$, showed that the highest bulk concentration in the lower $15 \mathrm{~cm}$ of the sea ice cores was $2.80 \mu \mathrm{g} \mathrm{l}^{-1}$ on 25 March (Fig. 4a). Subsequently, the algal biomass in the lower $15 \mathrm{~cm}$ of the sea ice cores decreased rapidly reaching a value of $1.50 \mu \mathrm{g} \mathrm{l}^{-1}$ in April.

Sea ice primary production integrated for the sea ice profile increased throughout winter from $0.09 \mathrm{mg} \mathrm{C}$ $\mathrm{m}^{-2} \mathrm{~d}^{-1}$ (15 February) to $12.60 \mathrm{mg} \mathrm{C} \mathrm{m}^{-2} \mathrm{~d}^{-1}$ (4 April) (Fig. 4b). The highest volume-specific primary produc-

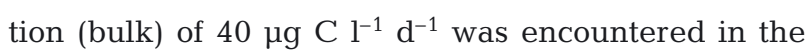
middle part of the sea ice profile in April.

The highest sea ice bacterial carbon demand of $27 \mu \mathrm{g} \mathrm{Cl}^{-1} \mathrm{~d}^{-1}$ was encountered in the central ice at the onset of the melting period (Fig. 4c). However, a single peak of $9.00 \mu \mathrm{g} \mathrm{C} \mathrm{l}^{-1} \mathrm{~d}^{-1}$ was observed on 10 March in the upper $10 \mathrm{~cm}$ section of the sea ice.

Depth integration of the activity reflected low autotrophic and heterotrophic productivity during winter, followed by a slightly net heterotrophic period in late February and March. Finally, a net autotrophic period was observed from late March until the end of the study period (Fig. 5). Integrated over the entire measuring season (i.e. from 15 February to 14 April) the sea ice of Malene Bight was net autotrophic. An annual net carbon fixation of $220 \mathrm{mg} \mathrm{C} \mathrm{m}^{-2}$ was calculated by subtracting the net result of a sea ice-related gross primary production of $350 \mathrm{mg} \mathrm{C} \mathrm{m}^{-2}$ from the bacterial carbon demand of $130 \mathrm{mg} \mathrm{C} \mathrm{m}^{-2}$.

\section{Bag incubations}

Oxygen levels during February and March indicated a low net oxygen accumulation in the top sea ice cores of $0.50 \pm 3.00 \mu \mathrm{mol} \mathrm{O} \mathrm{l}^{-1} \mathrm{~d}^{-1}$ (mean $\pm \mathrm{SD}$ ) and in the bottom sea ice cores of $1.30 \pm 5.00 \mu \mathrm{mol} \mathrm{O} \mathrm{l}^{-1} \mathrm{~d}^{-1}$. However, none of these values were significantly different from 
a) Chlorophyll ( $\mu \mathrm{g} \mathrm{I}^{-1}$ melted sea ice)

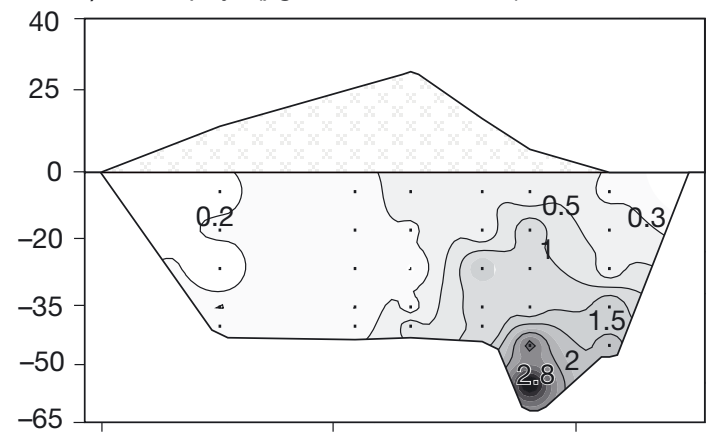

b) Primary production ( $\mu \mathrm{g} \mathrm{C} \mathrm{I}^{-1}$ melted sea ice $\mathrm{d}^{-1}$ )

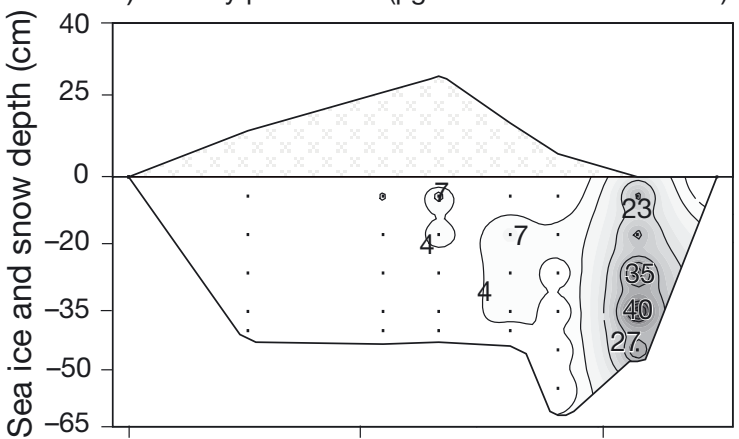

c) Bacterial carbon demand $\left(\mu \mathrm{g} \mathrm{Cl} \mathrm{I}^{-1}\right.$ melted sea ice $\left.\mathrm{d}^{-1}\right)$

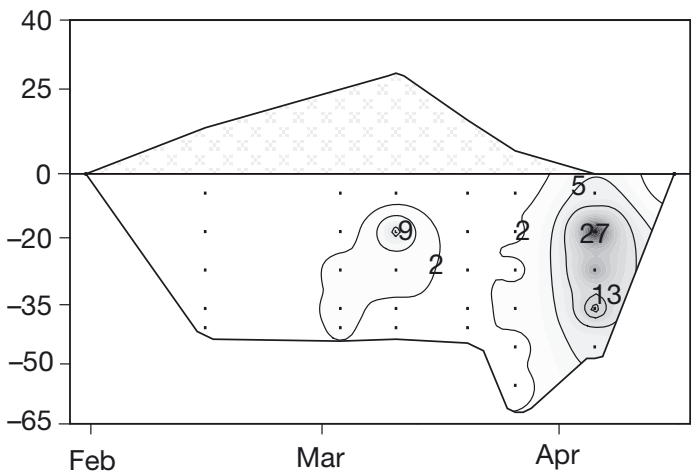

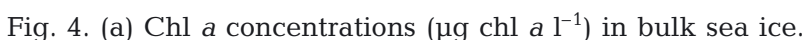
(b) Primary production ( $\mu \mathrm{g} \mathrm{Cl}^{-1}$ melted sea ice $\left.\mathrm{d}^{-1}\right)$. (c) Bacterial carbon demand ( $\mu \mathrm{g} \mathrm{C} \mathrm{l}^{-1}$ melted sea ice $\mathrm{d}^{-1}$ ) calculated according to Rivkin \& Legendre (2001). The black dots represent triplicate measurements

zero ( $p>0.05)$ (Fig. 6). Autotrophic activity exceeded heterotrophic activity in late March and April, resulting in a significantly high net oxygen accumulation in the bottom sea ice cores of $6.30 \pm 2.30 \mu \mathrm{mol} \mathrm{O}_{2} \mathrm{l}^{-1} \mathrm{~d}^{-1}(\mathrm{p}<$ 0.01 ) whereas no significant oxygen accumulation $\left(0.80 \pm 3.50 \mu \mathrm{mol} \mathrm{O}_{2} \mathrm{l}^{-1} \mathrm{~d}^{-1}\right)$ was observed in the top sea ice cores.

Assuming a photosynthetic quotient of $1.00 \mathrm{CO}_{2}$ evolved per $\mathrm{O}_{2}$ consumed, a net annual carbon fixation of $1700 \pm 760 \mathrm{~g} \mathrm{C} \mathrm{m}^{-2}$ was calculated for the bag incubations.

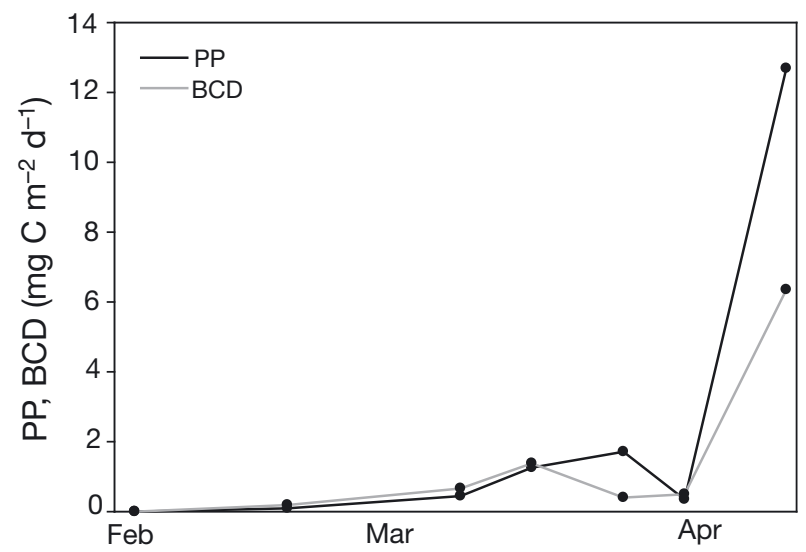

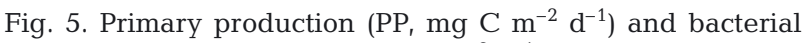
carbon demand ( $\mathrm{BCD}, \mathrm{mg} \mathrm{C} \mathrm{m}^{-2} \mathrm{~d}^{-1}$ ) in bulk sea ice

a) Top sea ice cores
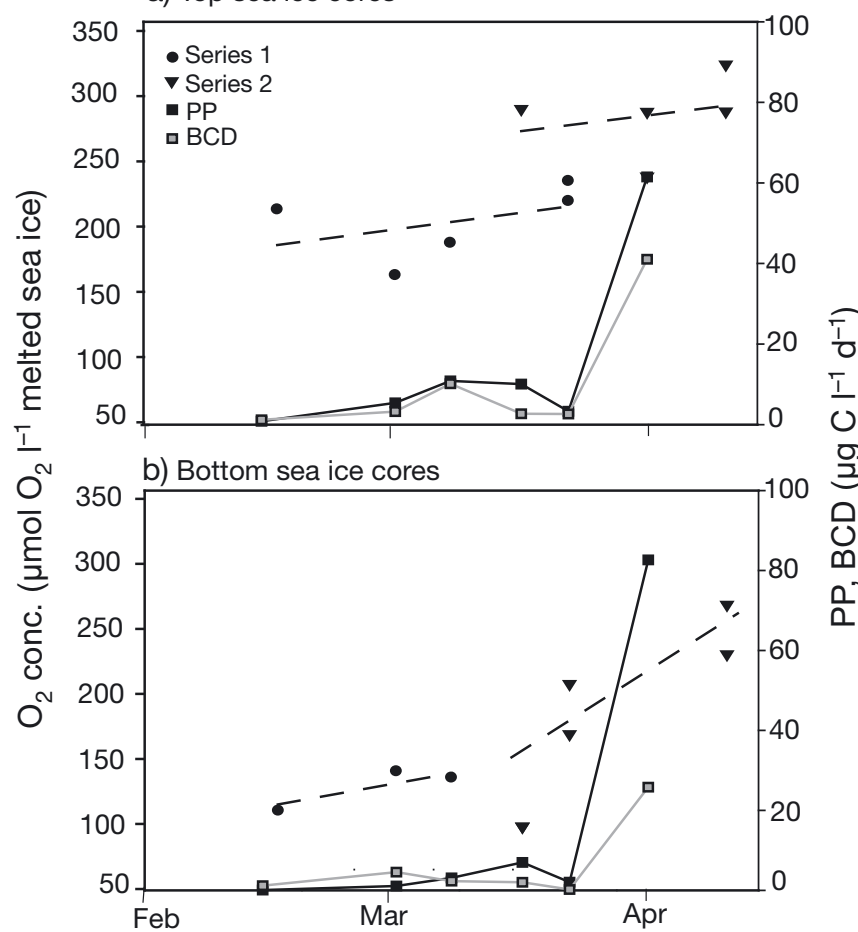

Fig. 6. Measurements of $\mathrm{O}_{2}$ concentration $\left(\bullet, \mathbf{v}: \mu \mathrm{mol} \mathrm{O}_{2} \mathrm{l}^{-1}\right.$

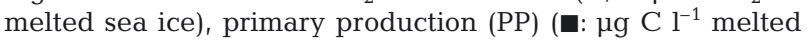
sea ice $\mathrm{d}^{-1}$ ) and bacterial carbon demand (BCD) ( $\square$ : $\mu \mathrm{g} \mathrm{C}^{-1}$ melted sea ice $\mathrm{d}^{-1}$ ) in (a) top half and (b) bottom half of sea ice cores. Dashed lines represent regression lines

\section{Heterogeneity}

On 23 February the abiotic and biotic conditions, i.e. bulk salinity, brine volume, temperature, chl $a$, primary production and bacterial carbon demand, were measured in top and bottom sections of the sea ice cores $(\mathrm{n}=10)$ along a $10 \mathrm{~m}$ transect (Table 1$)$. There 
Table 1. Abiotic and biotic parameters in sea ice of Malene Bight: bulk salinity, relative brine volume $(\%)$, temperature $\left({ }^{\circ} \mathrm{C}\right)$,

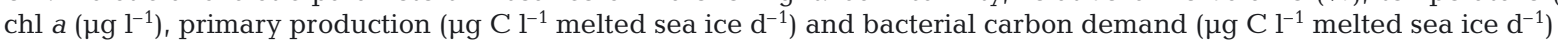

\begin{tabular}{|c|c|c|c|c|c|c|}
\hline & $\begin{array}{c}\text { Bulk } \\
\text { salinity }\end{array}$ & $\begin{array}{l}\text { Relative brine } \\
\text { volume }(\%)\end{array}$ & $\begin{array}{c}\text { Temperature } \\
\left({ }^{\circ} \mathrm{C}\right)\end{array}$ & $\begin{array}{c}\text { Chl a } \\
\left(\mu g l^{-1}\right)\end{array}$ & $\begin{array}{l}\text { Primary production } \\
\left(\mu \mathrm{g} \mathrm{C}^{-1} \text { melted }\right. \\
\left.\text { sea ice } \mathrm{d}^{-1}\right)\end{array}$ & $\begin{array}{l}\text { Bacterial carbon } \\
\text { demand }\left(\mu \mathrm{C}^{-1}\right. \\
\left.\text { melted sea ice } \mathrm{d}^{-1}\right)\end{array}$ \\
\hline Top sea ice & $2.06 \pm 0.13$ & $2.38 \pm 0.20$ & $-4.65 \pm 0.35$ & $0.15 \pm 0.09$ & $0.24 \pm 0.012$ & $0.37 \pm 0.06$ \\
\hline Bottom sea ice & $1.83 \pm 0.18$ & $3.09 \pm 0.39$ & $-3.15 \pm 0.39$ & $0.34 \pm 0.25$ & $0.36 \pm 0.012$ & $0.18 \pm 0.06$ \\
\hline
\end{tabular}

was a significant effect of depth on chl a levels (2-way ANOVA: $F_{1,19}=7.452, \mathrm{p}=0.023$ ) with the bottom section having a higher phototrophic biomass than the top section of the ice cores. The primary production rates were also highest in the bottom sections and lowest in the top sections (2-way ANOVA: $F_{9,19}=119.180, \mathrm{p}<$ 0.0005), while the bacterial carbon demand was higher in the top sections than in the bottom sections (2-way ANOVA: $F_{1,19}=6.521, \mathrm{p}<0.031$ ) (Table 1 ).

Along a $10 \mathrm{~m}$ transect there was no significant horizontal variation across all biotic and abiotic conditions (2-way ANOVA: $F_{9,19}=0.142, \mathrm{p} \geq 0.142$ ). However, for all the parameters there was a significant vertical variability (2-way ANOVA: $F_{5,49-50}=15.215$, p < 0.0005).

Performing a similar statistical analysis on the temporal variations showed that, for all conditions, there was a significant temporal variability (2-way ANOVA: $\left.F_{6,49-50}=37.157, \mathrm{p}<0.0005\right)$. Thus, for all conditions the horizontal variability in February was remarkably smaller than the seasonal variability.

Algal biomass (i.e. as chl a), bulk salinity and temperature in the lower section $(5 \mathrm{~cm})$ of the sea ice, and snow and sea ice thickness were measured along a $367 \mathrm{~m}$ transect to assess the horizontal distribution of these parameters. Moran's I was used to estimate the spatial autocorrelation within the data set (Moran 1950, Legendre \& Legendre 1998, Rysgaard et al.

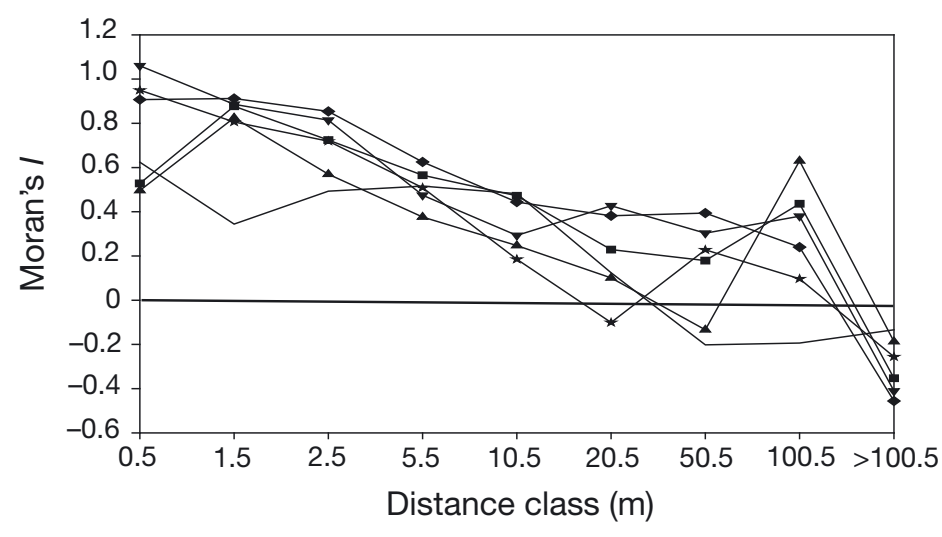

Fig. 7. Moran's $I$ as a function of distance class (m) between sites. $\star$ : temperature; $\mathbf{\Lambda}$ : bulk salinity; $\mathbf{v}$ : sea ice thickness; $\bullet$ : snow thickness; $\mathbf{~}$ : relative brine volume; —: chl a
2001). Positive or negative values indicated positive or negative autocorrelation, respectively. The change from positive to negative values of Moran's $I$ for $\mathrm{chl}$ a occurred from the $20.5 \mathrm{~m}$ distance class to the $50.5 \mathrm{~m}$ distance class (Fig. 7). This indicates that the average sea ice algae biomass patch radius was between 20.5 and $50.5 \mathrm{~m}$. The change from positive to negative values of Moran's I for sea ice temperatures and bulk salinity also occurred from the $20.5 \mathrm{~m}$ class of distance to the $50.5 \mathrm{~m}$ class of distance. In contrast, the average sea ice thickness, snow thickness and relative brine volume patch radius was $>100.5 \mathrm{~m}$, i.e. where the first change from positive to negative values of Moran's $I$ occurred.

\section{DISCUSSION}

Sea ice algae are known to be adapted to low ambient light levels and able to grow at light intensities as low as 7 to $20 \mu \mathrm{mol}$ photons $\mathrm{m}^{-2} \mathrm{~s}^{-1}$ (Gosselin et al. 1990, Gradinger \& Ikävalko 1998). Before April, snow cover inhibited any significant sea ice primary production ( $<1.5 \mathrm{mg} \mathrm{C} \mathrm{m}^{-2} \mathrm{~d}^{-1}$ ) due to high attenuation coefficients and low light availability $\left(<7 \mu \mathrm{mol}\right.$ photons $\mathrm{m}^{-2}$ $\mathrm{s}^{-1}$ ). As snow cover diminished, light availability increased to above $7 \mu \mathrm{mol}$ photons $\mathrm{m}^{-2} \mathrm{~s}^{-1}$ and sea ice algae began to flourish; thus, the community became net autotrophic as light availability increased late in the season.

The annual succession of the sea ice organisms in Malene Bight followed a distinctive pattern, with a winter stage in February and March characterised by low and almost balanced heterotrophic and autotrophic activities. During February and March, the oxygen level in the bag incubations remained constant, validating the low, balanced heterotrophic and autotrophic activity (Fig. 6). As light availability increased in late March and April the now net autotrophic community led to a significant net oxygen accumulation of $6.30 \pm 2.30 \mu \mathrm{mol} \mathrm{O} \mathrm{O}^{-1}$ in the bottom sea ice cores whereas no significant oxygen accumulation $\left(0.80 \pm 3.50 \mu \mathrm{mol} \mathrm{O} \mathrm{O}^{-1} \mathrm{~d}^{-1}\right)$ was observed in the top sea ice cores. 
To correctly assess primary production and heterotrophic activity it is essential to have insight into in situ light availability. In the present study, high snow reflectance caused strong light attenuation for most of the sea ice season. The snow attenuation coefficient varied (from 4 to $32 \mathrm{~m}^{-1}$ ) throughout the sea ice season with the highest attenuation coefficient of $32 \mathrm{~m}^{-1}$ found in March (Fig. 1b). The snow attenuation coefficients in Malene Bight were within the range of $<4$ to $40 \mathrm{~m}^{-1}$ reported by Weller \& Schwerdtfeger (1967) and Thomas (1963) for natural snow cover in the Arctic and Antarctic. Dry and fresh snow as observed in Malene Bight has a significantly higher light attenuation than did compressed or wet snow at subzero temperatures (Perovich 1996, Perovich et al. 1998, Glud et al. 2007), resulting in low in situ primary productivity as was observed in February and March.

The average attenuation coefficient of $8 \mathrm{~m}^{-1}$ in the sea ice of Malene Bight was also relatively high compared with the attenuation coefficient during the summer thaw as reported by Glud et al. (2007) and Lüthje et al. (2006). The air humidity above the ice in Malene Bight was, on average, only $70 \%$ and in areas with low air humidity, air pockets could form due to brine drainage from surface layer, resulting in a high degree of scatter and increasing attenuation coefficients (Perovich 1996, Andreas \& Ackley 1982, Trodahl \& Buckley 1990). Overall our data on snow and sea ice attenuations are generally higher than values reported elsewhere, and as snow cover regulates light availability and therefore spatial patchiness of ice algae (Gosselin et al. 1986, Rysgaard et al. 2001), the phototrophic rates obtained during the present study were low. Sea ice algal biomass ( $\mathrm{chl}$ a) patch size followed the snow and sea ice temperature patch size with an average radius of 20.5 to $50.5 \mathrm{~m}$ (Fig. 7). This suggests that snow cover and temperature (via brine volume) in sea ice were the main factors controlling sea ice algal patchiness. However, snow cover, temperature and light availability are crosscorrelated, and all exert a regulating effect on sea ice algal biomass in Malene Bight.

The maximum depth-integrated sea ice algal biomass of 0.07 to $0.5 \mathrm{mg} \mathrm{chl} \mathrm{a} \mathrm{m} \mathrm{m}^{-2}$ (Fig. 4b) was $>2$ orders of magnitude lower compared with the values of 50 to $150 \mathrm{mg} \mathrm{chl} \mathrm{a} \mathrm{m}{ }^{-2}$ that were reported by Arrigo (2003) to be common in Arctic sea ice. Likewise, primary production measurements were low during February and March but gradually increased during the season, reaching a peak activity of only $12.6 \mathrm{mg} \mathrm{C} \mathrm{m}^{-2} \mathrm{~d}^{-1}$ in early April, which is low compared with other studies (Arrigo 2003 and references therein). Integrated over the entire measuring period the annual sea ice algal carbon production was $350 \mathrm{mg} \mathrm{C} \mathrm{m}^{-2}$, which was $47 \%$ lower than measurements made in the neighbouring
Kobbefjord during 2006 (Mikkelsen et al. 2008). Furthermore, the sympagic primary production of $350 \mathrm{mg}$ $\mathrm{C} \mathrm{m}{ }^{-2}$ corresponded to $<1 \%$ of the annual pelagic primary production of the region (Juul-Pedersen et al. 2009).

The low biomass and primary production values of the sea ice in Malene Bight can be attributed to relatively low light availability and a relatively thick dense snow cover, which was also observed in NE Greenland by Glud et al. (2007). However, nutrient supply and different physical conditions, e.g. ice temperature, brine salinity and flushing of sea ice brine, and biological interactions also regulate the distribution and activity of sea ice organisms. The sea ice contained relatively high concentrations of $\mathrm{NH}_{4}{ }^{+}$, while $\mathrm{PO}_{4}{ }^{3-}$, $\mathrm{Si}(\mathrm{OH})_{4}$ and $\mathrm{NO}_{3}{ }^{-}+\mathrm{NO}_{2}{ }^{-}$concentrations in the sea ice were low (0.70 to $0.05 \mu \mathrm{mol} \mathrm{l}^{-1}, 2.30$ to $0.02 \mu \mathrm{mol} \mathrm{l}^{-1}$ and 3.2 to $0.5 \mu \mathrm{mol} \mathrm{l}^{-1}$, respectively (Figs. 2 \& 3 ). The algal biomass was low at the bottom of the sea ice after midMarch, suggesting that the sea ice biomass was nutrient-limited late in the sea ice season. Nutrient concentration in sea ice is affected by biological activity as well as by exchange of nutrients between the sea ice, water and atmosphere. Previous studies have shown that during sea ice formation, dissolved constituents (including inorganic nutrients) are rejected from the ice matrix (Clarke \& Ackley 1984, Giannelli et al. 2001). The nutrient-salt plots in Fig. 3 indicate that some import or accumulation of nutrients occurred during February and March. However, late in the sea ice season nutrients were generally depleted (Fig. 3), presumably due to microbial uptake (Fig. 4), which correlated with high primary productivity and a net autotrophic sea ice.

Plots of salinity- $\mathrm{NH}_{4}{ }^{+}$suggested $\mathrm{NH}_{4}{ }^{+}$enrichment, which occurred during the entire season, indicating an input from the atmosphere and/or heterotrophic activity by bacteria mineralising organic material encapsulated during sea ice formation. The standard laboratory-based incubations indicate a low net heterotrophic activity in February and March (Figs. 4 \& 5). Calculated average bacterial carbon demand in this period was $1.60 \mu \mathrm{g} \mathrm{Cl}^{-1} \mathrm{~d}^{-1}$. At a $\mathrm{C}: \mathrm{N}$ ratio of $7: 1$, this is equivalent to a remineralisation rate of $0.02 \mu \mathrm{mol} \mathrm{N}$ $\mathrm{l}^{-1} \mathrm{~d}^{-1}$, which is lower than the values of Riedel et al. (2007) who reported $\mathrm{NH}_{4}{ }^{+}$regeneration rates of 0.1 to $1.2 \mu \mathrm{mol} \mathrm{N} \mathrm{l} \mathrm{l}^{-1} \mathrm{~d}^{-1}$ corresponding to only $20 \%$ of the winter-spring increase in $\mathrm{NH}_{4}{ }^{+}$concentrations in the sea ice of Malene Bight. This suggests that $\mathrm{NH}_{4}{ }^{+}$ regeneration rates were not the main source of $\mathrm{NH}_{4}{ }^{+}$ accumulation in the sea ice. Thus, additional atmospheric input could potentially cause the high $\mathrm{NH}_{4}{ }^{+}$ concentrations in the sea ice of Malene Bight. In previous studies, high $\mathrm{NH}_{4}{ }^{+}$values in sea ice have been measured in Arctic and Antarctic sea ice caused by 
regeneration of nitrogen compounds within the sea ice (Thomas et al. 1995, Kaartokallio 2001, Riedel et al. 2007).

Bacteria production rates of 0.05 to $1.3 \mathrm{mg} \mathrm{C} \mathrm{m}^{-3} \mathrm{~d}^{-1}$ in Malene Bight compare with rates of 0.004 to $6.0 \mathrm{mg}$ $\mathrm{C} \mathrm{m} \mathrm{m}^{-3} \mathrm{~d}^{-1}$ reported by Kottmeier et al. (1987), 0.2 to $10 \mathrm{mg} \mathrm{C} \mathrm{m}{ }^{-3} \mathrm{~d}^{-1}$ by Grossmann \& Dieckmann (1994) and 2.9 to $5.6 \mathrm{mg} \mathrm{C} \mathrm{m}^{-3} \mathrm{~d}^{-1}$ by Mock et al. (1997).

The annual net bacterial carbon demand of $130 \mathrm{mg} \mathrm{C}$ $\mathrm{m}^{-2}$ was $37 \%$ of the co-occurring primary production of $350 \mathrm{mg} \mathrm{C} \mathrm{m}{ }^{-2}$. This observation is similar to findings reported in the world's oceans (Ducklow 1983) and in benthic systems (Fenchel \& Glud 2000). However, the ratio reported in the present study is significantly higher than the few percent reported from Antarctic (Kottmeier et al. 1987) and Arctic sea ice (Smith et al. 1989, Smith \& Clement 1990). Our bag incubations from winter, however, support results from our traditional standard incubations that a close connection exists between phototrophic and heterotrophic communities and, considering that both algae and bacteria are situated close together in the sea ice brine matrix, a tight metabolic coupling would be expected. Positive correlation has also been demonstrated in some sea ice habitats (e.g. Gradinger \& Zhang 1997, Meiners et al. 2003). However, limited data on the coupling between phototrophic and heterotrophic communities in sea ice exists and further investigations are required to elucidate the metabolic coupling in sea ice.

In the standard incubations, primary production of sea ice algae was determined by the ${ }^{14} \mathrm{C}$ method (Steeman-Nielsen 1952). One problem with this technique is that melting or crushing of sea ice is required to homogeneously distribute ${ }^{14} \mathrm{C}$ in the media, which separates organisms from the surrounding sea ice and alters the complex sea ice microenvironment. The photosynthetic performance may be considerably affected when the sea ice environment (i.e. irradiance, substrate, salinity, temperatures and spectral composition) is altered. Secondly, melting of the sea ice may influence algal abundance and species diversity (Gradinger et al. 1999). In the present study the samples were melted slowly $(48 \mathrm{~h})$ in darkness at $3 \pm 1^{\circ} \mathrm{C}$. In general decreasing or increasing salinity from that typical of seawater results in decreasing photosynthetic rates. Kirst \& Wiencke (1995) showed that most sea ice algae are more tolerant to reduced rather than elevated salinities. Salinity-induced stress to sea ice algae is light dependent, such that incubated samples only suffered photosynthetic damage when irradiance was applied (Ralph et al. 2007). Furthermore, a potential problem when melting sea ice samples in darkness is inactivation of phototrophs, which might remain inactive during a subsequent ${ }^{14} \mathrm{C}$ incubation period in light. However, sea ice algae can adapt to increasing light intensity within hours (Smith \& Sakshaug 1990). In addition, Peters \& Thomas (1996b) showed that some algae cells are able to sustain an active photosynthetic apparatus for months in darkness, which allows carbon assimilation immediately after reintroduction to light. Also, photosynthetic rates in sea ice algae can be influenced by temperature (Palmisano et al. 1987, Ralph et al. 2005). Optimum temperature for ice algal photosynthesis is between 2 and $15^{\circ} \mathrm{C}$, with a rapid decline in photosynthetic rate at temperatures above $15^{\circ} \mathrm{C}$ and below $-10^{\circ} \mathrm{C}$ (Bunt 1964, Palmisano et al. 1987, Kottmeier \& Sullivan 1988, Ralph et al. 2005). In the present study the sea ice was slowly melted at $3 \pm 1^{\circ} \mathrm{C}$; thus, the primary production was measured at higher temperatures than in situ. This suggests that the primary production might be overestimated in the winter period, where the difference between in situ temperature and laboratory temperature was greatest. However, it is a nontrivial task to incubate samples at low bulk salinity at $0^{\circ} \mathrm{C}$ or subzero temperature without introducing freezing and thawing artefacts. Overall, it is difficult to assess the extent to which our (and other) procedures for ${ }^{14} \mathrm{C}$ incubations result in under- or overestimation of the in situ primary production.

While calculation of phototrophic activity is relatively straightforward, the assessment of the bacteria production and bacterial carbon demand is based on a number of debatable assumptions. The method assumes that all bacteria assimilate exogenous thymidine and that eukaryotes do not. Uptake of $\left[{ }^{3} \mathrm{H}\right]$ thymidine by eukaryotic microalgae has been clearly demonstrated (Rivkin 1986). However, Fuhrman \& Azam (1980) have shown that at low concentrations and relatively short incubation periods the uptake of $\left[{ }^{3} \mathrm{H}\right]$ thymidine by eukaryotes should be negligible. The $\left[{ }^{3} \mathrm{H}\right]$ thymidine method is a widely used index of bacteria production but requires a conversion factor to relate DNA production to production of bacterial cells. In the present study, we extrapolated incorporation data to bacteria production by applying the early season data of Smith \& Clement (1990). They calculated the conversion factor for high Arctic sea ice bacteria as $2.09 \times$ $10^{18}$ cells mol $^{-1}$ in the early sea ice season and as $0.47 \times$ $10^{18}$ cells $\mathrm{mol}^{-1}$ in the late sea ice season. The conversion factor from the early sea ice season fell within the commonly reported range of 1 to $4 \times 10^{18} \mathrm{cells} \mathrm{mol}^{-1}$ (e.g. Fuhrman \& Azam 1982, Riemann et al. 1987), and Smith \& Clement (1990) suggested that this factor was more appropriate than the lower conversion factor from the late season. Other factors used for the conversion of thymidine incorporation into bacteria production include the average bacterial cell size $\left(\mathrm{Cell}_{\text {size }}\right)$ and the volume-specific carbon content $\left(C_{\mathrm{factor}}\right)$, which combined provide the cell-specific carbon content $\left(\mathrm{N}_{\mathrm{c}}\right)$ and which are affected by environmental changes 
(Coveney \& Wetzel 1988). Integrated over the entire measuring season, the sea ice of Malene Bight was net autotrophic. However, when using different $\mathrm{N}_{\mathrm{C}}$ factors discussed in the literature (Riemann et al. 1987, Smith \& Clement 1990, Gradinger and Zhang 1997, Kaartokallio et al. 2005), the annual bacterial carbon demand ranged by a factor of 6 from 70 to $400 \mathrm{mg} \mathrm{C}$ $\mathrm{m}^{-2}$ depending on which $\mathrm{N}_{\mathrm{c}}$ value is used. In the present study, we used an $\mathrm{N}_{\mathrm{c}}$ value measured in the high Arctic (Smith \& Clement 1990) and, thus, we observed an annual carbon demand of $130 \mathrm{mg} \mathrm{C} \mathrm{m}^{-2}$.

Rivkin \& Legendre (2001) reported that the bacterial growth efficiency was an inverse function of temperature. We used a growth efficiency measured in polar oceans of 0.50 (Rivkin \& Legendre 2001). However, small changes in temperature would influence growth efficiency and, hence, bacterial carbon demand $\left(\sim 2.5 \%\right.$ decrease in growth efficiency per $1^{\circ} \mathrm{C}$ increase). Using the 3 different growth efficiencies of 0.10, 0.25 and 0.90 (Bjørnsen 1986, Bjørnsen \& Kuparinen 1991, Gradinger \& Zhang 1997, Middelboe \& Søndergaard 1993, Rivkin \& Legendre 2001 and references therein, M. Middelboe \& R. Glud unpubl. data), the annual bacterial carbon demand ranged by a factor of 5 from 71 to $635 \mathrm{mg} \mathrm{C} \mathrm{m}^{-2}$ depending on the growth efficiency we used. The conclusion would change from an annual net autotrophic sea ice to a net heterotrophic sea ice if we used the growth efficiency of 0.10 . However, when using the growth efficiencies of 0.25 and 0.90 the sea ice is still net autotrophic. According to Rivkin \& Legendre (2001), growth efficiency increases with decreasing temperatures. Thus, the conversion of bacteria production to bacterial carbon demand by assuming a growth efficiency of 0.5 appears to be a realistic compromise among the conflicting literature values of 0.10 to 0.90 (Bjørnsen 1986, Bjørnsen \& Kuparinen 1991, Gradinger \& Zhang 1997, Middelboe \& Søndergaard 1993, Rivkin \& Legendre 2001 and references therein). It would be ideal to determine the respective factors at different seasonal conditions to improve the assessment of bacterial production and carbon demand, but in practice this would be an unrealistically large effort for most studies.

The $\mathrm{O}_{2}$ concentration of sea ice is regulated by photosynthesis and respiration (Gleitz et al. 1995, Günther et al. 1999) and is also affected by freezing and thawing of sea ice (Glud et al. 2002). The temporal and spatial variations in snow cover thickness can introduce variability in sea ice temperatures and consequently in $\mathrm{O}_{2}$ concentrations. During the present study, the snow cover varied from 0 to $26 \mathrm{~cm}$ and the sea ice temperature varied from 0 to $-6^{\circ} \mathrm{C}$ (Fig. 1a), and only slight changes in temperature can lead to leakage of supersaturated and subsaturated water from the sea ice matrix (Glud et al. 2002). It is generally accepted that to obtain realistic estimates of in situ microbial activity in sea ice, the microenvironment (i.e. temperature, salinity, nutrient concentration) should be maintained (e.g. McMinn \& Ashworth 1998). The bag incubations were incubated in situ and, thus, the sea ice microenvironment was better maintained compared with standard incubations. This supports the use of bag incubations for determination of net $\mathrm{O}_{2}$ production or consumption under natural conditions. In the present study, oxygen levels remained almost constant during February and March, indicating no or low net oxygen accumulation in the top sea ice cores of $0.50 \pm$ $3.00 \mu \mathrm{mol} \mathrm{O} \mathrm{l}^{-1} \mathrm{~d}^{-1}$ and in the bottom sea ice cores of $1.30 \pm 5.00 \mu \mathrm{mol} \mathrm{O}_{2} \mathrm{l}^{-1} \mathrm{~d}^{-1}$ (Fig. 6). The permeability of the bags was tested and could be responsible for a maximum $\mathrm{O}_{2}$ exchange of $0.48 \pm 0.20 \mu \mathrm{mol} \mathrm{O} \mathrm{O}^{-1} \mathrm{~d}^{-1}$, which may compromise the results in February and March when no or low net oxygen accumulation was observed.

The autotrophic activity exceeded the heterotrophic activity in late March and April, resulting in a high net oxygen accumulation in the bottom sea ice cores of $6.30 \pm 2.30 \mu \mathrm{mol} \mathrm{O} \mathrm{O}_{2} \mathrm{l}^{-1} \mathrm{~d}^{-1}$, whereas no significant oxygen accumulation occurred in the top sea ice cores $\left(0.80 \pm 3.50 \mu \mathrm{mol} \mathrm{O} \mathrm{O}_{2} \mathrm{l}^{-1} \mathrm{~d}^{-1}\right)$. The $\mathrm{O}_{2}$ measurements showed high variability, indicating small-scale heterogeneity in oxygen. Thus, we suggest that more replicates be applied from all time intervals to quantify net oxygen consumption or production in future studies.

The temperature of sea ice enclosed in the bags did not differ from the ambient temperature profiles (data not shown). However, enclosure might have a number of consequences for the measured microbial activity. In case of high sea ice algal primary production and low nutrient concentrations, enclosing sea ice cores in bags creates a risk of underestimating primary production, as nutrient consumption sets an upper limit to production. In the present study, primary production measured in the bags from the bottom of the sea ice during

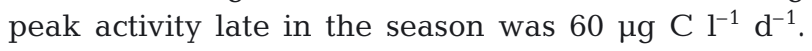
Assuming a $\mathrm{C}: \mathrm{N}$ Redfield ratio of 6.6 this represents a sufficient nitrogen pool for only $7 \mathrm{~d}$ of incubation. This indicates that the enclosed primary producers could have been nutrient-limited during the late part of the season (Fig. 6b), which suggests that oxygen production in the bottom sea ice section in the final incubation was underestimated. However, the annual net carbon fixation in the bag incubations was 8-fold higher than the annual net carbon fixation of $220 \mathrm{mg} \mathrm{C} \mathrm{m}^{-2}$ quantified from the standard incubations. We cannot, on this basis, pinpoint the reason for the apparent mismatch or evaluate which estimate is most correct. However, bags incubated for $<7 \mathrm{~d}$ create a minimum disturbance of the microenvironment within the sea ice and might be a strong complementary tool to standard techniques 
when assessing the net activity of microbial communities in sea ice. Hence, further work with the bag incubation technique in situ is clearly needed to better elucidate whether sea ice, on an annual scale, is net autotrophic or net heterotrophic.

Acknowledgements. We thank A. Haxen and M. R. Schrøder for assistance in field and laboratory, and T. Juul-Pedersen, K. Arendt, D. M. Mikkelsen and P. Batty for valuable comments. We are thankful for the irradiance data provided by Asiaq (Greenland Survey). This study received financial support from the Danish Agency for Science, Technology and Innovation, KVUK Commission for Scientific Research in Greenland, is a part of the Greenland Climate Research Centre (GCRC 6507) and is a contribution to the Nuuk Basic and Zackenberg Basic programmes.

\section{LITERATURE CITED}

Andreas EL, Ackley SF (1982) On the differences in ablation seasons of the Arctic and Antarctic sea ice. J Atmos Sci 39: $440-447$

Arrigo KR (2003) Primary production in sea ice. In: Thomas DN, Dieckmann GS (eds) Sea ice: an introduction to its physics, chemistry, biology and geology. Blackwell Science, Oxford, p 143-183

Bjørnsen PK (1986) Bacterioplankton growth yield in continuous seawater cultures. Mar Ecol Prog Ser 30:191-196

Bjørnsen PK, Kuparinen J (1991) Determination of bacterioplankton biomass, net production and growth efficiency in the Southern Ocean. Mar Ecol Prog Ser 71:185-194

Braman RS, Hendrix SA (1989) Nanogram nitrite and nitrate determination in environmental and biological materials by vanadium (III) reduction with chemiluminescence detection. Anal Chem 61:2715-2718

Brinkmeyer R, Knittel K, Jürgens J, Weyland H, Amann R, Helmke E (2003) Diversity and structure of bacterial communities in Arctic versus Antarctic pack ice. Appl Environ Microbiol 69:6610-6619

Bunch JH, Harland RC (1990) Bacterial production in the bottom surface of sea ice in the Canadian Subarctic. Can J Fish Aquat Sci 47:1986-1995

Bunt JS (1964) Primary productivity under sea ice in Antarctic waters. Influence of light and other factors on photosynthetic activities of Antarctic marine microalgae. Antarct Res Ser 1:27-31

Clarke DB, Ackley SF (1984) Sea ice structure and biological activity in the Antarctic marginal ice zone. J Geophys Res C4 89:2087-2096

Cota GF, Horne EPW (1989) Physical control of arctic ice algal production. Mar Ecol Prog Ser 52:111-121

> Coveney MF, Wetzel RG (1988) Experimental evaluation of conversion factors for the $\left[{ }^{3} \mathrm{H}\right]$ thymidine incorporation assay of bacterial secondary productivity. Appl Environ Microbiol 54:2018-2026

Cox GFN, Weeks WF (1983) Equations for determining the gas and brine volumes in sea-ice samples. J Glaciol 29: 306-316

Ducklow HW (1983) Production and fate of bacteria in the ocean. Bioscience 33:494-501

Fenchel T, Glud RN (2000) Benthic primary production and $\mathrm{O}_{2}-\mathrm{CO}_{2}$ dynamics in a shallow-water sediment: spatial and temporal heterogeneity. Ophelia 53:159-171

> Fuhrman JA, Azam F (1980) Bacterioplankton secondary pro- duction estimates for coastal waters of British Columbia, Antarctica, and California. Appl Environ Microbiol 39: 1085-1095

Fuhrman JA, Azam F (1982) Thymidine incorporation as a measure of heterotrophic bacterioplankton production in marine surface waters: evaluation and field results. Mar Biol 66:109-120

Giannelli V, Thomas DN, Haas C, Kattner G, Kennedy H, Dieckmann GS (2001) Behavior of dissolved organic matter and inorganic nutrients during experimental sea ice formation. Ann Glaciol 33:317-321

Gleitz M, vd Loeff MR, Thomas DN, Dieckmann GS, Millero FJ (1995) Comparison of summer and winter inorganic carbon, oxygen and nutrient concentrations in Antarctic sea ice brine. Mar Chem 51:81-91

> Glud RN, Rysgaard S, Kühl M (2002) A laboratory study on $\mathrm{O}_{2}$ dynamics and photosynthesis in ice algal communities: quantification by microsensors, $\mathrm{O}_{2}$ exchange rates, ${ }^{14} \mathrm{C}$ incubations and a PAM fluorometer. Aquat Microb Ecol 27: $301-311$

Glud RN, Rysgaard S, Kühl M, Hansen JW (2007) The sea ice in Young Sound: implications for C cycling. In: Rysgaard $\mathrm{S}$, Glud RN (eds) Carbon cycling in Arctic marine ecosystems: case study Young Sound. Bioscience Vol 58. Commission for Scientific Research in Greenland (Meddelser om Grønland), Copenhagen, p 62-85

Gosselin M, Legendre L, Therriault JC, Demers S, Rochet M (1986) Physical control of the horizontal patchiness of seaice microalgae. Mar Ecol Prog Ser 29:289-298

Gosselin M, Legendre L, Therriault JC, Demers S (1990) Light and nutrient limitation of sea ice microalgae (Hudson Bay, Canadian Arctic). J Phycol 26:220-232

Gosselin M, Levasseur M, Wheeler PA, Horner RA, Booth BC (1997) New measurements of phytoplankton and ice algal production in the Arctic Ocean. Deep-Sea Res II 44: 1623-1644

Gradinger R, Ikävalko J (1998) Organism incorporation into newly forming Arctic sea ice in the Greenland Sea. J Plankton Res 20:871-886

Gradinger R, Zhang Q (1997) Vertical distribution of bacteria in Arctic sea ice from the Barents and Laptev Seas. Polar Biol 17:448-454

Gradinger R, Friedrich C, Spindler M (1999) Abundance, biomass and composition of the sea ice biota of the Greenland pack ice. Deep-Sea Res II 46:1457-1472

Grasshoff K, Erhardt M, Kremling K (eds) (1983) Methods of seawater analysis, 2nd edn. Verlag Chemie, Wienhiem

> Grossmann S, Dieckmann GS (1994) Bacterial standing stock, activity, and carbon production during formation and growth of sea ice in the Weddell Sea, Antarctica. Appl Environ Microbiol 60:2746-2753

> Grossmann S, Gleitz M (1993) Microbial responses to experimental sea-ice formation: implications for the establishment of Antarctic sea-ice communities. J Exp Mar Biol Ecol 173:273-289

Günther S, Gleitz M, Dieckmann GS (1999) Biogeochemistry of Antarctic sea ice: a case study on platelet ice layers at Drescher Inlet, Weddell Sea. Mar Ecol Prog Ser 177:1-13

Hansen JW, Thamdrup B, Jørgensen BB (2000) Anoxic incubation of sediment in gas-tight plastic bags: a method for biogeochemical process studies. Mar Ecol Prog Ser 208: 273-282

> Holmes RM, Aminot A, Kérouel R, Hooker BA, Peterson BJ (1999) A simple and precise method for measuring ammonium in marine and freshwater ecosystems. Can J Fish Aquat Sci 56:1801-1808

Horner R, Schrader GC (1982) Relative contribution of ice 
algae, phytoplankton, and benthic microalgae to primary production in nearshore regions of the Beaufort Sea. Arctic 35:485-503

Jespersen AM, Christoffersen K (1987) Measurements of chlorophyll-a from phytoplankton using ethanol as extraction solvent. Arch Hydrobiol 109:445-454

Juul-Pedersen T, Rysgaard S, Batty P, Mortensen J and others (2009) Nuuk Basic: the marine basis programme 2008. In: Jensen LM, Rasch M (eds) Nuuk ecological research operations, 2nd Annu Rep 2008. National Environmental Research Institute, Aarhus University (Chapter 5)

Kaartokallio H (2001) Evidence for active microbial nitrogen transformations in sea ice (Gulf of Bothnia, Baltic Sea) in midwinter. Polar Biol 24:21-28

Kaartokallio H (2004) Food web components, and physical and chemical properties of Baltic Sea ice. Mar Ecol Prog Ser 273:49-63

Kaartokallio H, Laamanen M, Sivonen K (2005) Responses of Baltic sea ice and open-water natural bacterial communities to salinity change. Appl Environ Microbiol 71: 4364-4371

Kaartokallio H, Kuosa H, Thomas DN, Granskog MA, Kivi K (2006) Biomass, composition and activity of organism assemblages along a salinity gradient in sea ice subjected to river discharge in the Baltic Sea. Polar Biol 30:183-197

Kirst GO, Wiencke C (1995) Ecophysiology of polar algae. J Phycol 31:181-199

Kottmeier ST, Sullivan CW (1988) Sea ice microbial communities (SIMCO) 9. Effects of temperature and salinity on rates of metabolism and growth of autotrophs and heterotrophs. Polar Biol 8:293-304

Kottmeier ST, Grossi SM, Sullivan CW (1987) Sea ice microbial communities. VIII. Bacterial production in annual sea ice of McMurdo Sound, Antarctica. Mar Ecol Prog Ser 35:175-186

Krembs C, Eicken H, Junge K, Deming JW (2002) High concentrations of exopolymeric substances in Arctic winter sea ice: implications for polar ocean carbon cycle and cryoprotection of diatoms. Deep-Sea Res I 49:2163-2181

Legendre P, Legendre L (1998) Numerical ecology, 2nd edn. Developments in environmental modelling, Vol 20. Elsevier Science, Amsterdam

Leppäranta M, Manninen T (1988) The brine and gas content of sea ice with attention to low salinities and high temperatures. Finnish Inst Mar Res Internal Rep 88-2

Lizotte MP (2003) The microbiology of sea ice. In: Thomas DN, Dieckmann GS (eds) Sea ice: an introduction to its physics, chemistry, biology and geology. Blackwell Science, Oxford, p 184-210

Lüthje M, Feltham DL, Taylor PD, Worster MG (2006) Modeling the summertime evolution of sea ice melt ponds. J Geophys Res 111:C02001, doi:10.1029/2004JC002818

McMinn A, Ashworth C (1998) The use of oxygen microelectrodes to determine the net production by an Antarctic sea ice algal community. Antarct Sci 10:39-44

Meiners K, Gradinger R, Fehling J, Civitarese G, Spindler M (2003) Vertical distribution of exopolymer particles in sea ice of the Fram Strait (Arctic) during autumn. Mar Ecol Prog Ser 248:1-13

Middelboe M, Søndergaard M (1993) Bacterioplankton growth yield: seasonal variations and coupling lability and $\beta$-glucosidase activity. Appl Environ Microbiol 59: 3916-3921

> Mikkelsen DM, Rysgaard S, Glud RN (2008) Microalgal composition and primary production in Arctic sea ice: a seasonal study from Kobbefjord (Kangerluarsunnguaq), West Greenland. Mar Ecol Prog Ser 368:65-74
Mock T, Meiners KM, Giesenhagen HC (1997) Bacteria in sea ice and underlying brackish water at $54^{\circ} 26^{\prime} 50^{\prime \prime} \mathrm{N}$ (Baltic Sea, Kiel Bight). Mar Ecol Prog Ser 158:23-40

> Moran PAP (1950) Notes on continuous stochastic phenomena. Biometrika 37:17-23

> Palmisano AC, SooHoo JB, Sullivan CW (1987) Effects of four environmental variables on photosynthesis-irradiance relationships in Antarctic sea-ice microalgae. Mar Biol 94: 299-306

Perovich DK (1996) The optical properties of sea ice. US Army Cold Regions Research and Engineering Laboratory (CRREL) Monogr 96-1, Hanover, NH

Perovich DK, Roesler CS, Pegau WS (1998) Variability in Arctic sea ice optical properties. J Geophys Res 103: 1193-1208

> Peters E, Thomas DN (1996b) Prolonged nitrate exhaustion and diatom mortality: a comparison of polar and temperate Thalassiosira species. J Plankton Res 18:953-968

Platt T, Gallegos CL, Harrison WG (1980) Photoinhibition of photosynthesis in natural assemblages of marine phytoplankton. J Mar Res 38:687-701

Ralph PJ, McMinn A, Ryan KG, Ashworth C (2005) Shortterm effect of temperature on the photokinetics of microalgae from the surface layers of Antarctic pack ice. J Phycol 41:763-769

Ralph PJ, Ryan KG, Martin A, Fenton G (2007) Melting out of sea ice causes greater photosynthetic stress in algae than freezing in. J Phycol 43:948-956

Reimnitz E, Marincovich L Jr, McCormick M, Briggs WM (1992) Suspension freezing of bottom sediment and biota in the Northwest Passage and implications for Arctic Ocean sedimentation. Can J Earth Sci 29:693-703

Riedel A, Michel C, Gosselin M, Leblanc B (2007) Enrichment of nutrients, exopolymeric substances and microorganisms in newly formed sea ice on the Mackenzie shelf. Mar Ecol Prog Ser 342:55-67

Riemann B, Bjornsen PK, Newell S, Fallon R (1987) Calculation of cell production of coastal marine bacteria based on measured incorporation of $\left[{ }^{3} \mathrm{H}\right]$ thymidine. Limnol Oceanogr 32:471-476

Rivkin RB (1986) Incorporation of tritiated thymidine by eukarotic microalgae. J Phycol 22:193-198

Rivkin RB, Legendre L (2001) Biogenic carbon cycling in the upper ocean: effects of microbial respiration. Science 291: 2398-2400

Rysgaard S, Glud RN (2004) Anaerobic $\mathrm{N}_{2}$ production in Arctic sea ice. Limnol Oceanogr 49:86-94

> Rysgaard S, Kühl M, Glud RN, Hansen JW (2001) Biomass, production and horizontal patchiness of sea ice algae in a high-Arctic fjord (Young Sound, NE Greenland). Mar Ecol Prog Ser 223:15-26

> Smith REH, Clement P (1990) Heterotrophic activity and bacterial productivity in assemblages of microbes from sea ice in the high Arctic. Polar Biol 10:351-357

Smith WO Jr, Sakshaug E (1990) Polarphytoplankton. In: Smith WO Jr (ed) Polar oceanography. Part B. Chemistry, biology and geology. Academic Press, San Diego, CA, p $477-525$

Smith REH, Clement P, Cota GF (1989) Population dynamics of bacteria in Arctic sea ice. Microb Ecol 17:63-76

Steeman-Nielsen E (1952) The use of radio-active carbon $\left({ }^{14} \mathrm{C}\right)$ for measuring organic production in the sea. J Cons Int Explor Mer 18:117-140

Strickland JDH, Parsons TR (1972) A practical handbook of seawater analysis. Fish Res Board Can Bull 167, Ottawa

Thomas CW (1963) On the transfer of visible radiation through sea ice and snow. J Glaciol 4:481-484 
Thomas DN, Lara RJ, Eicken H, Kattner G, Skoog A (1995) Dissolved organic matter in Arctic multi-year sea ice during winter: major components and relationships to ice characteristics. Polar Biol 15:477-483

Trodahl HJ, Buckley RG (1990) Enhanced ultraviolet transmission of Antarctic sea ice during the austral spring. J Geophys Res 17:2177-2179

Vézina AF, Demers S, Laurion I, Sime-Ngando T, Juniper SK, Devine L (1997) Carbon flows through the microbial food

Editorial responsibility: Graham Savidge,

Portaferry, UK web of first-year ice in Resolute Passage (Canadian High Arctic). J Mar Syst 11:173-189

Weeks WF, Ackley SF (1986) The growth, structure and properties of sea ice. In: Untersteiner N (ed) The geophysics of sea ice. NATO ASI Series Ser B Physics. Plenum Press, New York, NY, p 9-164

Weller G, Schwerdtfeger P (1967) Radiation penetration in Antarctic plateau and sea ice. In: Polar meteorology. World Meteorol Org Tech Note 87:120-141

Submitted: January 8, 2010; Accepted: September 27, 2010

Proofs received from author(s): November 26, 2010 